\title{
The Canadian University Selectivity Premium
}

\author{
JONIADA MILLA \\ Sobey School of Business \\ Saint Mary's University*
}

\begin{abstract}
This paper surveys the recent empirical literature on wage premium to university selectivity, and provides new evidence to this literature on a country such as Canada that has a distinct higher education system from those already analyzed. I estimate the wage premium to university selectivity using Canadian data and two popular methods to correct for non-random selection in universities of different quality: matching methods and instrumental variables (IV). I estimate a wage premium of $7 \%$ using the matching estimator, and a premium of $14.8 \%$ using the IV estimator for alumni of selective Canadian universities 4-6 years after graduation. My findings are in line with the literature on countries with a moderately differentiated higher education system that has low variation in tuition fees and is well supported by public funds.
\end{abstract}

Keywords: University selectivity, Wage premium, Context

JEL Classification: C21, I23, J30

\section{Introduction}

Labor market prospects for recent graduates depend mainly on their acquired skills, ability and work productivity. In particular, the last two are unobservable characteristics. From an employer's point of view, an inexpensive instrument that is often used as a signal for these unobserved attributes is the prestige, reputation, quality or selectivity at admission of post-secondary institution where the potential employee received their degree. Hence, employers statistically discriminate based on two possible scenarios that point them to the better applicant for the job: either because better universities attract and skim the better students (hence, inherently productive employees), or because better universities make better graduates (everything else equal). As a result, the employees' employability and wage rates would differ. The differences in labor market outcomes may also reflect benefits from peer effects or a better alumni network that more selective

\footnotetext{
* joniada.milla@smu.ca. While the research and analysis are based on data from Statistics Canada, the opinions expressed do not represent the views of Statistics Canada. I am thankful to Thanasis Stengos, Michael Hoy, Miana Plesca, Adeline Delavande, Louis Christofides, Justin Smith, Mikal Skuterud and Elena Mattana for useful feedback on a previous draft.

(C) 2018 Joniada Milla; . Licensed under the Creative Commons Attribution - Noncommercial 3.0 Licence (http://creativecommons.org/licenses/by-nc/3.0/. Available at http: //rofea.org.
} 
universities offer. I survey the literature that recognizes and attempts to separate two main sources of wage differentials: sorting of students at admission and the added value (university training, peer or network effects) from studying in a selective ${ }^{1}$ university. This remains a challenging task given the lack of consensus in estimated wage returns to university selectivity. A non-contestable outcome of this survey is the differences in estimates with respect to the context of the higher education (HE) systems under evaluation.

The literature on university selectivity premium on wages ${ }^{2}$ is vast and focuses mainly on countries with a polarized education system (such as the U.S., Columbia or Chile), where the differences in university selectivity are evidently large. This paper revisits the question of wage premium to university quality in a different context, such as the Canadian one. The Canadian case is interesting and different from the countries that have been investigated in the literature. In Canada the most prestigious universities ${ }^{3}$ are public universities, relying at an almost equal extent on public and private funds. The per-student public funding to Canadian universities is relatively homogeneous, even though it varies by province. Although not yet shown analytically, the variation in Canadian universities' selectivity falls between the selective HE systems in the Americas (U.S., Chile, Colombia that have high tuition fees with a relatively high variance and select students based on a standardized entry exam), and the publicly funded HE systems in the E.U. that are equally endowed in terms of public resources, charge very low/no tuition with low variance and admit students based on their high school grade point average (GPA). In the later context, as expected the university selectivity premium is lower than in the former.

The main novelty of this paper is to provide the first study using Canadian data that addresses non-random sorting of students to different universities at the admission stage. The reason behind the lack of other research on the topic is due to

${ }^{1}$ I use the term university "selectivity" rather than quality or reputation. The latter two terms delegate the cause of wage differential to a source, but the first term is viewed as a catchall term for the effect that university standing has on wages (Broecke, 2012, p.97).

${ }^{2}$ The university selectivity wage premium refers to the average wage differential of employees that except for the selectivity of the universities they have completed, have similar characteristics such as high school grades, non-cognitive skills, aspirations for post-secondary education, family background, major choice, occupation and experience in the labor market.

${ }^{3}$ Differently from the United States, in Canada college and university refer to different academic entities. In Canada, colleges offer vocational trades programs and Bachelorequivalent degrees in arts and sciences focused on practical aspect of learning. College instructors in Canada focus on teaching and have extensive experience in the private sector. Universities offer Bachelor degrees with research opportunities leading to graduate studies. 


\section{MILLA Canadian University Selectivity Premium}

the absence of crucial information in Canadian surveys such as the name of the university that individuals completed. To the best of my knowledge, the only other paper that asks how university characteristics affect graduates' earnings for Canada is Betts et al. (2013). They provide a descriptive analysis using the Canadian National Graduates Survey. This dataset contains in- formation on the name of the university, but lacks a measure for individuals' academic ability prior to enrollment. I use a new, previously unexploited data, the Canadian Youth in Transition Survey (YITS), which is the first Canadian data to contain both the above information and more: the high school grades as measure of ability; the name of the university that they enrolled and graduated from; and the province of residence while in high school, university and when last interviewed. This data also offers rich and detailed background information on individuals, their families, high school experience, and a measure of their performance during their first academic year in university (their grade point average). The YITS also contains information on generally unobserved characteristics such as aspirations, student-elicited rating of their skills on communication, problem solving and math skills. In addition, there is available information on the frequency at which the student volunteered, and the number of on- and off-campus clubs that the student is actively engaged in. I leverage the large set of variables in the YITS to correct for the non-random sorting of students at admission stage into universities of different selectivity.

Although the YITS has an unusual set of information on university graduates, the possibility that other unobserved characteristics of individuals (e.g. non-cognitive skills) that guide sorting into universities of different quality and/or wage differentials cannot be ruled out unambiguously. To address this concern, I use an instrumental variable estimator in line with Long (2008). The exclusion restriction that this study uses (namely, the average selectivity measure for the institutions within a geographic radius of the student's high school residence) leads to a local average treatment effect (LATE) estimate reflecting mainly the wage premium of the subsample of students who live in regions with better universities, which in turn makes them more likely to attend a better university. Consequently, the students that reallocate to attend a better university from regions that originally do not favor them in this respect, are in fact weighted relatively less. It is likely that the expected returns to university quality are higher for these students that are willing to invest more. I propose a second exclusion restriction that offers a new source of exogeneity, and potentially leads to a LATE estimate of the wage premium with better external validity properties because it is representative of both students who attend a university close to their parents' home or those move out to a different province to do so. In addition to the Long (2008) 
instrument, I also use the difference of the average university selectivity between the students' pre-university residence region and the residence region while at university.

In this paper, I use all the three types of selectivity measures used in the literature: the average high school grade of the entering cohort (which is the main admission criteria in Canada), the "Best Overall Reputation Ranking" (hereafter Reputation Ranking) published yearly by the Maclean's magazine, and I also construct a quality measure using dimension reducing techniques in line with previous literature. Using the distribution of the selectivity measures and the university type (research, teaching intensive or both) I group the universities into three groups from most to least selective: A, B and C. I find that graduates of selective Canadian universities (group $A$ and $B$ ) earn $7 \%$ higher hourly wages than graduates of less selective universities (group C). These returns are not driven by differences in high school GPA (sorting of students at admission) or other student characteristics that are available in the YITS. The instrumental variable estimates (around $8-14.8 \%$ ), that are free of bias from unobserved characteristics, are higher in magnitude than the matching estimates, but the difference is statistically insignificant. Overall, the findings are in line with the literature on university selectivity that estimates a wage premium of $15-28 \%$ for graduates of the most selective universities in countries with a strongly differentiated HE system, and a premium of $2-7.4 \%$ in countries with moderately differentiated HE system.

The rest of the paper is organized as follows. I present a literature review in Section 2 while describing the Canadian HE system in comparison to that of other countries analyzed in the literature. I introduce the main specification and discuss the methodology in Section 3, the data in Section 4, and the results in Section 5. Section 6 concludes.

\section{Literature Review}

In this section I present a review of the literature on wage premium of university quality. All the papers discussed conduct the analysis of selectivity premium at the undergraduate level, ${ }^{4}$ their outcome of interest is the graduates' private wage rate, they conduct a quantitative empirical analysis, and they acknowledge and attempt to

\footnotetext{
${ }^{4}$ Even though excluded from this literature survey, it is important to note that the selectivity of graduate studies has been studied for the MBA program (Chen et al., 2012; Grove and Hussey, 2011), and the university selectivity at the undergraduate level has also been shown to affect other non-monetary outcomes such as dropping out behavior (Hanushek et al., 2008), college completion (Cohodes and Goodman, 2014; Heil et al., 2014), attending graduate school and expectations on wages (Loyalka et al., 2012), choice of siblings' PSE (post-secondary education) institution (Goodman et al., 2015), marriage market (Kaufmann et al., 2013), intergenerational effects (Kaufmann et al., 2014), PSE exit exam scores (Saavedra and Saavedra, 2011), and social returns such as becoming a more involved citizen through voting behavior (Solis, 2013).
} 


\section{MILLA Canadian University Selectivity Premium}

address the non-random selection of students in universities of different quality. In Table 1, I provide a tabulation of the wage premium estimates to university selectivity by estimation method and country.

\subsection{Estimation Method}

In the early literature, the premium to university quality is most often explored using cross- sectional data and a "selection on observables" approach (Heckman and Robb, 1985). ${ }^{6}$ The majority of these studies find a positive and significant premium of university quality on earnings. The recent literature has been more concerned with causal inference, and employs seven different approaches to address the non-random selection of students in universities of different quality as shown in Table 1: (i) Least Squares (LS) estimator is presented as the benchmark; (ii) Matching Estimator (ME); (iii) sibling or twin Fixed Effects estimator (FE); (iv) Self-revelation (SR) model suggested by Dale and Krueger (2002); (v) Applicant-matched (AM) model also suggested by Dale and Krueger (2002); (vi) Instrumental Variables (IV) estimator as suggested in Long (2008); (vii) and the Regression Discontinuity Design (RDD) method introduced by Thistlewaite and Campbell (1960) and reviewed by Lee and Lemieux (2010) for the empirical economist. Data and setting limitations allow me to use in this paper three of the above approaches when analyzing Canadian data: the linear LS estimator, ME and IV. I discuss the advantages and disadvantage of all seven methods below and conclude that wage premium estimates show consistency across the different methods but vary by type of education system.

As seen from Table 1, for the same country (and sometimes using the exact same data such as in Long (2008), Broecke (2012), Borgen (2014)) the different methods deliver different results. There are advantages to each of these methods, as there are weaknesses in their application. The main advantage of the matching estimator as argued in Black and Smith (2004) is to allow for a non-restrictive functional form, in contrast with the conventional linear least squares estimator (LS). The weakness of both methods is its reliance on the available information in the data and the "selection of observables" assumption. Among the studies that follow these two estimation methods, Brewer et al. (1999) and Lang and Siniver (2011) differ slightly in their approach. Brewer et al. (1999) use a model-based correction to address the self-selection issue but they find a significant premium of $20 \%$ that remains

\footnotetext{
${ }^{5}$ The approach assumes that wage premium estimates do not suffer of omitted variable bias as long as the model controls for all observable and measurable characteristics of individuals. Therefore, it rules out the existence of any unmeasurable omitted variable.

${ }^{6}$ For example, Brewer and Ehrenberg (1996), Dearden et al. (2002), Monks (2000), Behrman et al. (1996), Loury and Garman (1995), and James et al. (1989).
} 
Review of Economic Analysis 10 (2018) 313-349

Table 1: Wage Premium (\%) to University Selectivity by Estimation Method and Country

\begin{tabular}{|c|c|c|c|c|c|c|c|c|}
\hline Country & Study & LS & $\mathrm{ME}$ & FE & SR & $\mathrm{AM}$ & IV & $\mathrm{RDD}$ \\
\hline China & Hartoga et al. (2010) & $28^{\mathrm{g}}$ & & & & & & \\
\hline US & Brewer et al. (1999) & $20^{\mathrm{sd}}$ & & & & & & \\
\hline US & Long (2010) & $5^{\text {sd }}$ & & & & & & \\
\hline US & Andrews et al. (2016) & $\begin{array}{l}10-- \\
21^{\mathrm{g}}\end{array}$ & & & & & & \\
\hline US & Black (2005) & $\begin{array}{l}10-- \\
21^{\mathrm{g}}\end{array}$ & & & & & & \\
\hline US & Black (2004) & $11--$ & $15--$ & & & & & \\
\hline US & $\begin{array}{l}\text { Brand and Halaby } \\
(2006)\end{array}$ & $19^{\mathrm{g}}$ & $14^{\mathrm{g}, \mathrm{IN}}$ & & & & & \\
\hline US & Long (2008) & $2^{\text {sd }}$ & $13.4^{\mathrm{g}}$ & & $-13^{\mathrm{sd}, \mathrm{IN}}$ & & $26_{\mathrm{N}}^{\mathrm{sd}, \mathrm{I}}$ & \\
\hline US & Dale and Krueger (2002) & $8^{\mathrm{h}}$ & & & $-2^{\mathrm{h}, \mathrm{NN}}$ & & & \\
\hline US & & & & & & $0.1^{\mathrm{h}, \mathbb{N}}$ & & \\
\hline US & Behrman et al. (1996) & $21.2^{\mathrm{g}}$ & & & & & & \\
\hline US & Hoekstra (2009) & & & $19.1^{\mathrm{g}}$ & & & & $18^{\mathrm{g}}$ \\
\hline Chile & $\begin{array}{l}\text { Bordon and Braga } \\
(2014)\end{array}$ & $\begin{array}{l}11.5^{\mathrm{sd}} \\
; 26^{\mathrm{g}}\end{array}$ & & & & & & $\begin{array}{l}6.5-- \\
8^{\mathrm{g}}\end{array}$ \\
\hline Colombia & Saavedra (2009) & & & & & & & $20^{\mathrm{g}}$ \\
\hline Israel & Lang and Siniver (2011) & $9--21^{\mathrm{g}}$ & & & & & & \\
\hline UK & $\begin{array}{l}\text { Chevalier and Conlon } \\
(2003)\end{array}$ & & & & & & & \\
\hline UK & Hussain et al. (2009) & $6^{\text {sd }}$ & & & & & & \\
\hline UK & Walker and Zhu (2017) & $10^{\mathrm{g}, \mathrm{LR}}$ & & & & & & \\
\hline UK & Britton et al. (2016) & $6^{\mathrm{g}, \mathrm{LR}}$ & & & & & & \\
\hline UK & Broecke (2012) & $\begin{array}{l}9.7^{\mathrm{sd}} \\
20^{\mathrm{g}}\end{array}$ & & & $\begin{array}{l}5--7^{\mathrm{sd}} \\
16--22^{\mathrm{g}}\end{array}$ & $4--6^{\text {sd }}$ & & \\
\hline Italy & $\begin{array}{l}\text { Triventi and Trivellato } \\
\text { (2012) }\end{array}$ & & $2^{\mathrm{g}, \mathrm{IN}}$ & & & & & \\
\hline Italy & $\begin{array}{l}\text { Brunello and Capellari } \\
\text { (2008) }\end{array}$ & $7.4^{\mathrm{g}}$ & & & & & & \\
\hline Norway & Borgen (2014) & $2^{\text {sd }}$ & & $1.5^{\mathrm{sd}}$ & $2^{\text {sd }}$ & & $5^{\mathrm{sd}, \mathrm{LR}}$ & \\
\hline Sweden & $\begin{array}{l}\text { Lindahl and Regner } \\
\text { (2005) }\end{array}$ & $7^{\mathrm{g}}$ & & $4^{\mathrm{g}}$ & & & & \\
\hline Australia & Birch et al. (2009) & $\begin{array}{l}0.6-- \\
1.6^{\mathrm{g}}\end{array}$ & & & & & & \\
\hline
\end{tabular}

$\mathrm{LS}=$ Least Squares estimator with an identification strategy that relies on a rich set of covariate.

$\mathrm{ME}=$ Average Treatment on the Treated effect estimated by the nearest neighbor (NNM) or the propensity score (PSM) matching.

$\mathrm{FE}=$ Sibling or Twin Fixed Effects estimator.

$\mathrm{SR}=$ Dale and Krueger (2002) Self-revelation Model

$\mathrm{AM}=$ Dale and Krueger (2002) Applicant-Matched Model

$\mathrm{IV}=$ Instrumental Variable estimator using the exclusion restriction as proposed in Long (2008).

$\mathrm{RDD}=$ Regression Discontinuity Design.

$\mathrm{IN}=$ Indicates that the estimate is statistically insignificant and not different from zero. 


\section{MILLA Canadian University Selectivity Premium}

$\mathrm{LR}=$ Indicates estimates on earnings that are recorded more than 5 years after graduation

$\mathrm{Sd}=$ Indicates that the premium estimate corresponds to per one standard deviation of the composite quality index/university characteristic used in the respective paper.

$\mathrm{H}=$ Indicates that the premium estimate corresponds to per one hundred points of the average SAT/GMAT/entry exam score used in the respective paper.

$\mathrm{g}=$ Indicates that the premium estimate corresponds to an elite/top university grouping with respect to the prestige/reputation/ranking that is determined by the category/type of the institution or by the top quartile of the selectivity measure used in the respective paper.

unaffected by the correction. Lang and Siniver (2011) investigate the earnings of an elite university's graduates, and compare those to a non-elite college that they claim is similar in many aspects except for the reputation in the labor market. This may be viewed as a match based on university characteristics, rather than individuals' characteristics.

The sibling/twin fixed effects (FE) estimator, first introduced in Behrman et al. (1996), is a within-household estimator and the FE purges all the genetically identical but unobserved and omitted characteristics that the siblings share.

This approach implicitly assumes that the university choices are random within family (see Harmon et al., 2003, for the same discussion on returns to years of education). However, Goodman et al. (2015) shows that this is clearly not the case. This is why both Behrman et al. (1996) and Borgen (2014) find that the FE estimates are statistically not different from the LS estimates.

The SR model, and more so the AM model, are viewed as a more rigorous way of control- ling for the unobserved motivation, aspiration and ambition of the students, which is assumed to be revealed by the average selectivity of the universities where each individual applied but was not admitted. The AM model is more specific in that it explicitly matches the students that have been accepted and rejected by the same universities and compares their earnings. Using U.S. data these two methods deliver low and insignificant estimates of the premium (Dale and Krueger, 2002; Dale and Krueger, 2014; Long, 2008), but when using U.K. data the wage premium estimate is substantial and statistically significant (Broecke, 2012).

There have been two attempts in the literature so far with the use of instrumental variables. Long (2008) estimates a high but insignificant premium for the U.S. universities, but Borgen (2014) finds a 5\% increase on the earnings of Norwegian graduates as the university selectivity measure increases by a standard deviation. As I discuss in section 3.3, the reason for the high estimates is related to the local nature of the IV estimator that based on the source of exogeneity of exclusion restrictions.

Finally, the RDD method is viewed as the "closest cousin" (Lee and Lemieux, 2010) of experimental designs. However, external validity is often absent and can lead to high premium estimates of $18-20 \%$ as in Hoekstra (2009) and Saavedra (2009). This may be due to the fact that the studies can only use enrollees of one institution (the most selective) in the country as the treatment group, which leads one to question 
the external validity of the estimates. In contrast, Bordon and Braga (2014) are able to use information from all universities and estimate a wage premium to university selectivity of $6.5-8 \%$.

\subsection{Higher Education System Context}

The tabulation of estimates by country of data and estimation method highlights the fact that the context of higher education (HE) systems being analyzed is an important dimension of variation in premium estimates. The main differences are in the following characteristics:

(i) the source of funding (public funds vs. private tuition), (ii) the instruments they use to select students for admission (high school grades, standardized university entry exams, and other information related to non-analytical skills of the students), (iii) the dominance of the private HE sector in the country and its relative reputation in comparison to the public sector, (iv) and the variation in tuition fees. The relative variance of tuition fees, rather than the relative mean, may be used as a measure for the degree of differentiation among the HE systems, while relying on the assumption that price (tuition) reflects the quality of the product (human capital transmitted by universities).

Based on the above features, HE systems may be divided into three groups. The first group includes the severely selective systems with high variation in tuition fees, a private and reputable university sector, and use as admission criteria the scores on a standardized entry exam. Examples include China, Chile, the United States, the United Kingdom (Hartoga et al., 2010; OECD, 2007). The HE system of Israel is also similar in admission procedures as the countries above, except that the public institutions are the most selective ones that also ask for lower tuition fees. Therefore, characteristics of the tuition fees distribution is not informative of the selectivity differentiation in this case, as otherwise discussed above.

The second group includes those HE systems that are in the most part, if not fully, supported by public funds (i.e. tuition-free) where obtaining HE is considered a human right, not a privilege. Examples are the European Nordic countries like Sweden, Norway and Finland (OECD, 2016, pg. 238). The universities in this group admit students based on their high school GPA. These countries have a very small private sector that is less selective than the public institutions. The third group includes the HE systems that borrow similarities from the above two HE system types and have moderately differentiated universities. Examples are Italy and Australia (Birch et al., 2009; Hoxby, 1997; Triventi and Trivellato, 2012). In these countries the universities' main source of funds is the government, the private sector is small (e.g.: 10\% of enrollment in Italy), the tuition fees are moderate and have a low variation, and students are admitted based on their high school grades. 


\section{MILLA Canadian University Selectivity Premium}

The Canadian HE system shares similar features with the third group. Higher education in Canada ${ }^{7}$ is a provincial (not federal) jurisdiction, which led to the potentially most decentralized system in the developed world. Although there is no unique national system of education (each of the provinces have their own), the university sector features a homogeneous and uniform structure with a relatively low variation in public resources endowed to each institution. Tuition fees are lower than those of the universities in the first group, and have a much lower variation. There are relatively few universities in number ${ }^{8}$ and students are admitted to universities based on their high school grade point average. In line with the above discussion, the estimates found in the literature that I summarize in Table 1 are higher for the countries with a strongly differentiated university system such as the U.S., Chile, Colombia, Israel and the U.K. The selectivity premium is smallest for Australia, and moderate for Italy, Norway and Sweden. In this paper I show that the selectivity premium for Canada is closest in magnitude to the universities in the latter group.

\section{Methodology}

\subsection{Regression Model}

In this section, I describe the estimation procedures that are used in this paper. I estimate equation (1), that defines individual $i$ 's earnings in logarithmic form, $\log (w)$, as a function of university $j$ 's selectivity, $S_{j}$, the set of individual, family and institution characteristics, $X_{i j}$, and an idiosyncratic error term, $u_{i j}$. The main interest of the paper lies in estimating parameter $\beta_{1}$ in equation (1).

$$
\log (w)_{i j}=\beta_{0}+\beta_{1} S_{j}+\beta_{2} X_{i j}+u_{i j}
$$

I use three different estimation strategies in pursuit of correcting for the sorting of students into better universities based on individual characteristics and ability. I use least squares and matching methods to correct this endogeneity based on a very rich set of student characteristics that are available in the data. I also use an instrumental variable approach to control for potential presence of unobserved variables that could guide sorting. I describe below the latter two approaches.

\footnotetext{
${ }^{7}$ For a historical overview of the evolution of the Canadian higher education system see Jones (2014).

${ }^{8}$ There are 77 public and 13 private universities across Canada. Because of the limited data available on university characteristics, I have 46 universities in my sample, all of which are public. In the US, this number is much higher; for instance Black and Smith (2006) report 398 colleges in their sample. control for the potential presence of unobserved (and thus omitted) variables that could guide sorting. I describe below the latter two approaches.
} 


\subsection{Matching Estimator}

Black and Smith (2004) point out that matching methods outperform least squares by allowing for a non-linear selection on observable characteristics and thus do not impose a functional form on the type of dependency between the outcome and the covariates. They also show that the two methods yield different results. King and Nielsen (2016) show that matching on the propensity score lags behind other types of matching methods because it produces matches of lower quality that leads to biased coefficient estimates and lower efficiency. Following these suggestions in the literature, I use a multivariate nearest neighbor matching (NNM) estimator. The underlying assumption of matching methods is that, conditional on the pre-treatment variables, assignment to treatment is independent of the outcome of interest. The matching estimator requires that the treatment variable be of a binary nature, indicating the treatment and the comparison group. In this paper, the treatment group includes all individuals that graduated from a top university (classification is described in section 4), and the comparison group includes those that graduated from universities of lower selectivity.

The method finds matches with similar traits and attributes in the comparison group for each treated individual in the sample. In this paper, I select the closest matches (or neighbors) by minimizing the Euclidean distance between the characteristics of the treated individual and of similar neighbors in the comparison group. Hence, the treatment and the comparison group must contain sufficient overlap in the values of the pre-treatment variables for matching to be feasible. I allow matching with replacement, i.e. each individual in the comparison group may be used more than once as a match for different treated individuals. This reduces the estimation bias by yielding better matches. Once the closest matches have been selected for each treated individual, the counterfactual is estimated as the mean of their outcomes (wages). The mean of the differences in wages of the treated individuals and the corresponding counterfactual is the estimates of the Average Treatment on the Treated (ATT) parameter.

Empirical papers using matching methods report almost always the ATT estimate, assuming that in theory it should be equal to the Average Treatment on the Control (ATC) parameter. In a randomized control trial experiment these two parameters are equivalent. In this paper I compare the estimates of ATT and ATC (Average Treatment on the Control) to provide important insights with respect to the balancing property of the sample.

\subsection{Instrumental Variables}

In order to take into account any remaining sorting, not accounted by the available information in the data, I use an instrumental variable technique. Leveraging the available 


\section{MILLA Canadian University Selectivity Premium}

information, the YITS, I construct two instrumental (exclusion restrictions) variables to extract the exogenous variation in university selectivity, $S_{j}$ in equation (1). Both instruments are available for the same individuals in the data, and are used simultaneously in the IV results presented in section 5.2.

The first instrument is similar to the one used in Long (2008). The author proposed the use of average selectivity of universities within student's residential area during high school. Since students tend to attend a university not far away from their parents' home, and possibly in commuting distance, the distance from home may play a crucial role when choosing a university. The reasons are obviously related to travel and living costs given that Canada is a large and dispersed country. The geographic region in my case is the province where the student studied the last two years of high school. Given that the higher education system is a provincial jurisdiction, province-specific policies, regulations, rules and economic conditions introduce exogenous variation in the quality of universities. The instrument in this case exploits the exogenous variation in sorting that originates from the university selectivity differences across provinces.

This instrument highlights the wage premium earned by the students who attended a better university because of the availability of better universities in proximity. The comparison group in this case are the students who went to a less selective university because of a high proportion of low ranked universities in their province, which lowers their likelihood of attending a highly ranked university. For these students (stayers) the return on their investment for a BA degree is higher than for the students that have to invest on moving and living costs away from their parents' household in addition to tuition fees. However, if these students (movers) are willing to undergo these investments in order to attend a more selective university, then they must be expecting that the returns would compensate for this investment.

With this in mind, the second instrument that I construct exploits the difference in average university selectivity between the province of the students' high school and that of the university. The variable takes a positive value when students moved (in order to attend university) to a province with higher average university selectivity than their high school province, a zero value (by construction) when students choose to go to a university in the same province as their high school, and a negative value for those that attended a university in a province with lower average university selectivity than their high school province. This instrument leads to a LATE estimate that weights relatively more the students that reallocate to a province with a higher average university selectivity and also attend a top university. The aim is to estimate a LATE that is representative of both students that attend a selective university just because many are available in proximity, and of those students that are willing to reallocate to a different province in order to attend a selective university. 


\section{Data}

\subsection{Individual characteristics}

The main data set used in this paper is the older cohort of the Youth in Transition Survey (YITS). Individuals born between 1979-1981 were surveyed every two years starting in 2000. They were then followed for eight years until the last interview, which was conducted in 2008 .

The final sample excludes individuals with disabilities (4.3\%), high school dropouts (4.81\%), high school graduates $(24.54 \%)$, and those whose educational status is unknown $(2.89 \%)$. In the last cycle of the YITS, among the individuals who had completed some postsecondary education (PSE), 47\% reported having completed a PSE program which is less than a Bachelor's degree (college degree, vocational, trades etc.) 9 and $15 \%$ a program that is higher than a Bachelor'degree (First Professional Degree, Master's, Ph.D., or post-graduate certificate/diploma). Since their wage structure is different from what it is for a regular Bachelor's degree graduate, these two groups are excluded from the final sample. For the main analysis, I focus on respondents who have attained a Bachelor's degree. In the end, the sample of Bachelor's degree graduates who were working full-time is composed of 1,476 individuals who were 26-28 years old by December 2007.

The outcome of interest is the hourly wage rate of the respondents 4-6 years after graduating from a university program and are reported as of December 2007. The unusual quality and information in the data allow for a large set of covariates to be included as controls in the regression analysis. These include:

I. measures of academic aptitude: the high school grades (High school GPA), and the grades at the end of the first year in the university (GPA in First Year University). These are reported in the following categories: $90-100 \%, 80-89 \%$, $70-79 \%, 60-69 \%$, and $50-59 \%$ or lower intervals. In the regression model I use dummy variables indicating the two highest categories ${ }^{10}$;

II. measures/proxies for inter-personal skills: an indicator variable if the individual ever volunteered (Volunteering, taking value of 1 if ever

\footnotetext{
${ }^{9}$ Canada has the highest rate of tertiary education qualification in the adult population $(51 \%$ in 2011, (OECD, 2013)), and this is mostly due to the community college education system available in Canada.

${ }^{10}$ Since high school grades are self-reported, there is always the risk that they may be overstated. However, in the YITS the students were asked to report a grade interval. This procedure significantly reduces the risk of measurement error.
} 


\section{MILLA Canadian University Selectivity Premium}

volunteered and 0 if not), a measure in hour intervals per week ${ }^{11}$ dedicated to participation in school clubs, teams, or school organizations (Participation in School Clubs, taking value of 1 if participated and 0 if not) and non-school clubs $^{12}$ (Participation in Non-school Clubs), a self-reported 1- 5 Likert scale rating of own writing and speaking skills in explaining ideas to others, speaking to an audience and participating in discussions (Communication Skills), a self- reported 1-5 Likert scale rating of own ability to identify problems and possible causes, to plan strategies, to solve problems or think of new ways to solve problems (Problem Solving Skills), a self-reported 1-5 Likert scale rating of own ability to use formulas to solve problems, interpret graphs or tables, using math to figure out practical things in everyday life (Math Ability). The last three variables enter the regression equation as a dummy indicator of value 1 for reporting very good to excellent rating and 0 for other ratings;

III. demographic characteristics: age of the individuals (Age), a gender indicator (taking a value of 1 if student is female and 0 if male), race/community indicators (for each variable taking a value of 1 if reported black, aboriginal, or visible minority and 0 otherwise), an indicator for command in both English and French (value of 1 if reported an English and French speaker and 0 otherwise), an indicator for disability that does not impede any aspect of working (reported disability takes value 1 and 0 if no disability is reported), a single marital status indicator (taking value of 1 if single and 0 otherwise), an indicator for rural residence (Rural, taking value of 1 if residing in rural area and 0 otherwise), and province of residence dummy variables (British Columbia, Quebec, Manitoba and Saskatchewan, Alberta, or Atlantic Provinces, Ontario is the reference category);

IV. family characteristics: a dummy variable of value 1 when at least one parent reports some PSE qualification and zero otherwise (Parents PSE), a dummy variable of value 1 if student thought that getting PSE was important for their parents and 0 otherwise (PSE important for parent), and a dummy variable that takes a value of 1 if the respondent reports at least one older sibling (Older sibling);

\footnotetext{
${ }^{11}$ Categories range between 0 and 5, where 0 indicates no participation, 1 indicates less than 1 hour per week, 2 indicates between 1-3 hours per week, 3 indicates between 4-7 hours per week, 4 indicates between 8-14 hours and 5 indicates more than 15 hours per week.

12 These include non-school clubs, teams, volunteer work or other organizations, for example community sports, music lessons or youth groups not organized through school.
} 
V. high school characteristics: a dummy variable of value 1 when high school is private and 0 if public (High school private), a dummy variable of value 1 when student reports consuming alcohol more than once a week during high school and 0 otherwise (Alcohol Consumption Indicator) which is used as a proxy for misbehavior, and a peer-effect variable reported by the student in the form of a dummy variable of value 1 if the student reports that their closest high school friends planned to continue their education into PSE and 0 otherwise (Friends plan PSE) (see e.g. Christofides et al., 2015);

VI. university-related variables: duration in months of undergraduate studies as shown to be important by Black and Smith (2004) and Black et al. (2005), dummy variable indicators for three major groups of fields of study: Social Sciences, Humanities and Arts; Business Administration and Commerce; and Sciences, Technology, Engineering and Mathematics (STEM);

VII. job characteristics: experience in months following graduation (Experience), a set of dummy variable indicators for three occupation groups: Management, Business, Finance and Administration; Natural and Applied Sciences; and Social Sciences, Education and Governmental Service. The omitted category is the fourth group: Art, Culture, Recreation and Sports; Sales, Service and other.

Table A.1 contains the summary statistics for the aforementioned individual characteristics, and Table A.2 displays the correlation coefficients among these variables. On average they are 27 years old. The estimation sample is composed of $56 \%$ females, $16 \%$ visible minority, $5 \%$ report to have a disability that does not restrict their full working potential, more than $79 \%$ report having older siblings and $54 \%$ of them have at least one parent with PSE education, and $86 \%$ report that attaining higher education is important for their parents. In the sample $9 \%$ of the students attended a private high school, more than $70 \%$ have a high school GPA higher than $80 \%$, and more than half rate themselves as very good or excellent in communication, problem-solving and math skills. About $62 \%$ report having volunteered at least once, $21 \%$ to have consumed alcohol at least once a week while in high school, and about half report to have friends with PSE aspirations. On average individuals spend 1-3 hours/week engaged in school clubs, and about 4-7 hours/week in non-school clubs. With respect to their PSE experience, about $28 \%$ report a GPA in their first year university to be above $80 \%$. On average the undergraduate studies take 13 semesters to complete. The average hourly wage is 25.37 dollars per hour. The respondents report on average 42 months (or 3.5 years) of post- 


\section{MILLA Canadian University Selectivity Premium}

graduation work experience. The sample has an almost uniform distribution across the occupation and field of study groups.

\subsection{University characteristics and the quality measures}

A remaining challenge in the literature of university selectivity premium is to properly measure selectivity. Several university characteristics are used individually or all together in a regression equation to capture the quality of educational institutions. Examples include faculty-student ratio, faculty salaries, enrollment, retention rate, publications per researcher, and applicants per place (Behrman et al., 1996; Betts et al., 2013; Dearden et al., 2002). Noticing a high correlation between these characteristics, some papers either use a single, most important variable (Dale and Krueger, 2002; Long, 2010) or use data reduction techniques to combine several characteristics in one comprehensive index (Black and Smith, 2004; Long, 2008). Other papers use a published quality ranking (Brewer et al., 1999; Monks, 2000). In fact Black and Smith (2006) presents evidence in favor of using several proxies rather than a single one, and if one should be used they argue that the aver- age university entry exam score is the most reliable measure of selectivity in the U.S. I use three different selectivity measures: (1) the average GPA of entering cohort (GPA), (2) the Maclean's magazine Overall Reputation Ranking (RR), and (3) the Composite Index (CI) that I construct using several university characteristics.

I link the YITS to university characteristics from publicly available data. From the university ranking issue of Maclean's magazine published in November 2002, the year when the majority of students in the sample started university. I retrieve the following variables from the magazine's data: the Overall Reputation Ranking, the average high school grade point average of the entering cohort (Entering Cohort GPA), the percentage of full-time faculty with a Ph.D. degree (Faculty with Ph.D.), the number of students and full-time professors per 1000 who have won national awards in the past five years (Student Awards and Faculty Awards, respectively), and the number of Social Sciences and Humanities Research Council and Canada Council research grants per 100 full-time faculty members (Number Research Grants). From the 2002 CAUT Almanac (CAUT, 2002) I retrieve the ratio of full-time tenured faculty to the number of students enrolled (Faculty-Student Ratio).

First, in Canada the main admission criteria is the high school GPA. Therefore, I use the average high school grade point average as one of the selectivity measures.

Second, the Reputation Ranking, is constructed by the Maclean's magazine. They conduct a survey on high school counselors, university officials, CEOs and corporate recruiters across Canada and ask them to rank universities based on three attributes: best 
quality, most innovative, and leaders of tomorrow. Then, Maclean's calculates a best overall Reputation Ranking as a simple average of the rankings on the three attributes. Therefore, this measure is based mainly on the experience that the individuals surveyed have had with graduates from the different universities and subjective perceptions of the relative quality of the human capital transmitted.

Third, the composite index is viewed as an objective measure of university selectivity. Following the literature (Black and Smith, 2004, 2006; Long, 2008), I construct this index by using a dimension reduction technique, in this case the Principal Component Analysis (PCA), to combine a set of university characteristics into a single index. PCA yields linear orthogonal combinations of the variables by assigning weights to each. These weights are determined by the solution of an optimization problem that maximizes the extent to which the index accounts for the correlation (and not the covariance since the inputs are in different units) between university characteristics. I use the first principal component of the orthogonal transformation as the Composite Index. This is an efficient and commonly used method in the literature to combine many university characteristics into one index without worrying about multicollinearity when, otherwise, they would be used jointly as covariates in a regression equation. Table A.3 provides a list of the university characteristics, that I use to build the Composite Index, and their descriptive statistics. Table A.4 shows the correlation coefficients among these variables. As mentioned in the introduction, most of the variables are highly correlated.

The Maclean's magazine classifies Canadian universities into three types: (1) Medical/Doctoral Universities, which are the universities that have medical schools and a broad range of $\mathrm{PhD}$ programs and research; (2) Comprehensive Universities, which are the universities that have a significant degree of research activity and a wide range of programs at the undergraduate levels, including professional degrees; and (3) Primarily Undergraduate Universities, which includes the universities that are largely focused on undergraduate education, with relatively fewer graduate programs and graduate students.

In order to define the university selectivity groups, I use the above classification of university together with the selectivity measured described above. Table 2 summarizes the definition of selectivity groups, which are built separately for each of the three measures (GPA, RR and CI). Group A includes the Medical/Doctoral universities that also rank within the top (forth) quartile of the selectivity measure's distribution. Group B includes the Comprehensive universities that rank in the top half of the selectivity measure's distribution and the Medical/Doctoral universities that rank within the third quartile. Group $\mathrm{C}$ includes all remaining universities. The list of universities in each group is shown in Table A.5. 


\section{MILLA Canadian University Selectivity Premium}

Table 2: Explaining the ranking group classification

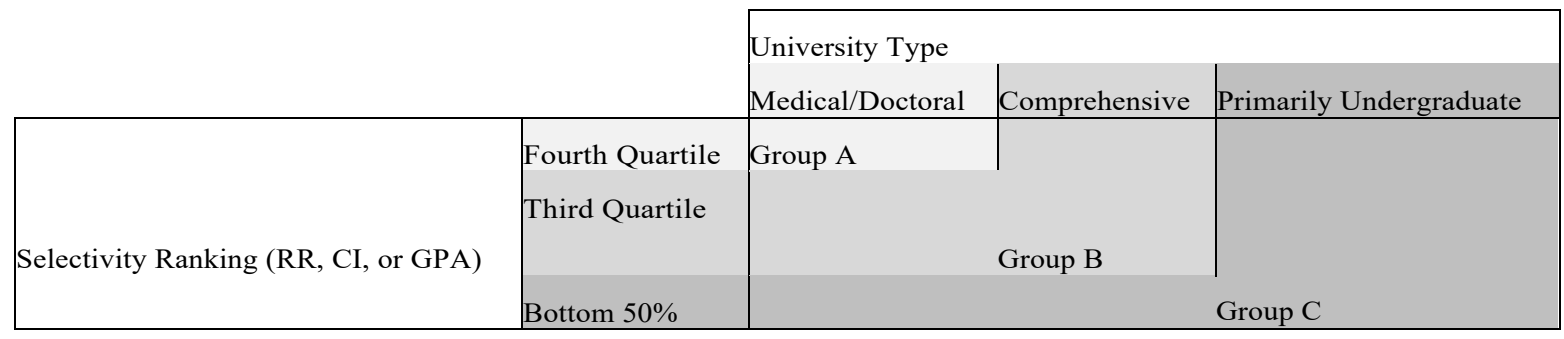

Students in the YITS graduated from 93 different universities. Even though the university data from the magazines were available for only 49 universities, I could match $79 \%$ of the students in the YITS to their universities in the external data. The high match rate is because the magazine reports on the biggest universities in the country, that are also the ones that agree to participate in the ranking. The number of observations (students per university) were very low for three universities which I exclude from the final sample.

\section{Results}

\subsection{Matching estimates}

In this section I discuss the multivariate matching estimates of the university selectivity premium on wages along with the least squares estimates, a benchmark in the literature (see Table 1). I plot in Figure 1 the wage distribution by university selectivity group (A, B and C) of the graduates for each of the three selectivity measures (GPA, RR, CI). There is no obvious differences in the graduates earnings distributions. Group C university graduates' distribution is centered more to the left than the other two, but the difference is negligible.

Table 3 contains the wage premium estimates. The matching estimator requires that the treatment variable takes the form of a bivariate zero-one indicator. Therefore, I construct the treatment indicator to be a dummy variable. The first treatment variable takes the value one if the university that the student graduated from belongs to Group A, and zero if it belongs to Group B or C (columns (1)-(3) in Table 3). The second treatment variable takes a value one if the university belongs to Group A or B, and zero if it belongs to Group C (columns (4)-(6) in Table 3).

The least squares (LS) regressions include all covariates described in Table A.1 and the quadratic of experience. The coefficient estimates in the first panel of Table 3 indicate a $1-3 \%$ premium on the hourly wage rate, but it is statistically insignificant in all cases. These results are in line with the similarities of the distributions shown in Figure 1. 
Figure 1: Wage distribution by university selectivity group

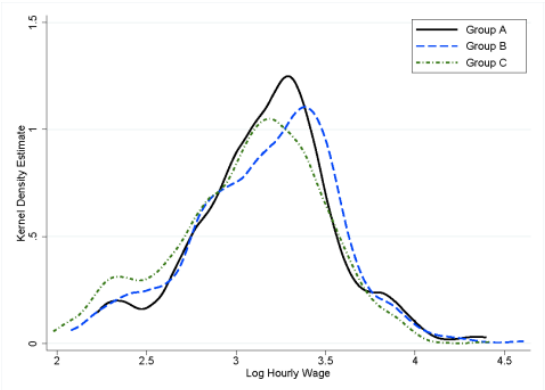

(a) GPA

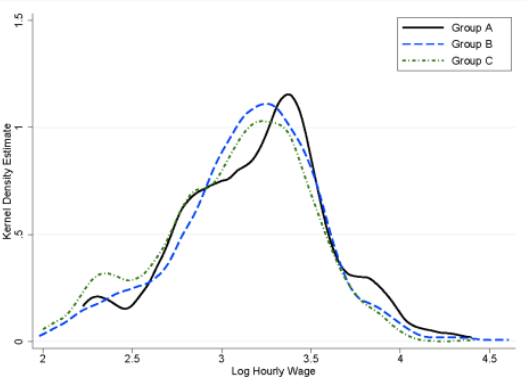

(b) RR

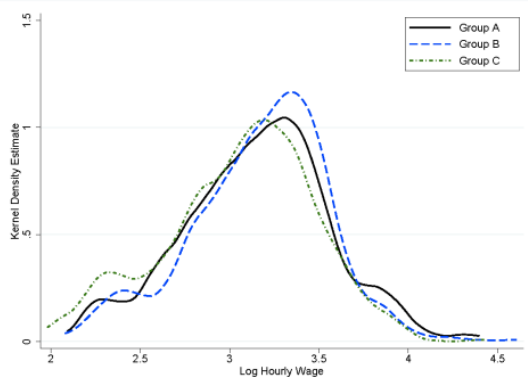

(c) $\mathrm{CI}$

The selectivity measures are the following: Entering Cohort GPA (GPA), Reputation Ranking (RR), and the Composite Index (CI).

The LS estimator weights each observation equally, in contrast with the matching estimator and the IV estimator (discussed in the next subsection) which weight the observations non-equally. In addition, the matching estimator also does not impose the linear functional form restriction as LS estimator does. Differently from the LS estimates, the average treatment effects on the treated (ATT) estimates in Table 3 are higher in magnitude, and statistically significant in the last three columns. Graduating from a Group A or B university earns their alumni a $6-7 \%$ premium on the hourly wage rate, when compared to Group $\mathrm{C}$ university graduates. The estimate is consistent across the three different selectivity measures (GPA, RR, CI).

I report the ATC estimates in the third panel of Table 3, as a diagnostic check for the balancing property on the treatment and comparison groups. In the ideal setting of experimental data, the two groups would be well balanced (i.e. very similar in terms of observable characteristics) and the estimates of ATT and ATC would be identical as a result. This is because it would not matter if we decide to find a match for each treated individual, or for each untreated individual since due to the composition of the two groups would lead one to find identical matches in both cases. As seen from 
MILLA Canadian University Selectivity Premium

Table 3: Least squares and matching estimates of wage premium

Group A vs. B \& C Group A \& B vs. C

\begin{tabular}{llllll}
\hline GPA & RR & CI & GPA & RR & CI \\
$(1)$ & $(2)$ & $(3)$ & $(4)$ & $(5)$ & $(6)$
\end{tabular}

\begin{tabular}{lccclll}
\hline \multicolumn{5}{l}{ Least Squares Estimates } \\
coef. & 0.031 & 0.004 & 0.005 & 0.030 & 0.013 & 0.027 \\
s.e. & 0.026 & 0.030 & 0.029 & 0.026 & 0.025 & 0.024 \\
R-sq & 0.287 & 0.286 & 0.286 & 0.287 & 0.286 & 0.287 \\
\hline Matching & Estimates, ATT & & & & \\
coef. & 0.032 & 0.041 & 0.016 & $0.067 * * *$ & $0.059 * * *$ & $0.072 * * *$ \\
s.e. & 0.028 & 0.032 & 0.029 & 0.023 & 0.023 & 0.024 \\
\hline Matching Estimates, ATC & & & & \\
coef. & $0.094 * * *$ & $0.056 *$ & $0.069 *$ & $0.091 * * *$ & $0.113 * * *$ & $0.099 * * *$ \\
s.e. & 0.033 & 0.030 & 0.027 & 0.024 & 0.024 & 0.023 \\
\hline $\mathrm{N}$ & 1476 & 1476 & 1476 & 1476 & 1476 & 1476 \\
\hline
\end{tabular}

Treatment and comparison groups are indicated at the top of the columns. Standard error estimates are weighted and robust. The list of covariates not shown in the table is as listed and described in section 4.1. The treatment variables are defined as shown is Table 2 using the university type and the respective selectivity measure: Entering Cohort GPA (GPA), Reputation Ranking (RR), and the Composite Index (CI). ATT $=$ Average Treatment on the Treated. ATC $=$ Average Treatment on the Control. coef. $=$ Coefficient estimate. s.e. $=$ Standard error estimate. R-sq=R-squared. $\mathrm{N}=$ Sample size. $* * * p<0.01, * * p<0.05, * p<0.10$.

Table 3, the estimates of ATT and ATC, even though not identical, they yield similar results, which in most cases are statistically not different (except for column (1) and (2)). ${ }^{13}$

\subsection{Instrumental variable estimates}

Following the description of the estimation approach in Section 3.3, in this subsection I discuss the instrumental variable estimates that are shown in Table 4.

In the third panel of the table I show the unconditional correlation coefficients between the endogenous variable (university selectivity) and the instruments (average selectivity measure in student's high school province and the difference from that of province where student studied university), which are higher than those reported in Long

${ }^{13}$ The more commonly used balance test for matching estimates (Smith \& Todd, 2005) is left out of the paper in favor of space, but the tables are available from the author. Results are similar to those presented in the paper. 
(2008) and Borgen (2014) and vary between 0.13-0.63. The first stage regressions indicate that the instruments are both relevant, except for column (2). I report the Hansen J-test of overidentifying restrictions (Hansen, 1982). In all cases the test indicates that the instruments are valid and not correlated with the error term.

Table 4: Instrumental variable estimates of wage premium

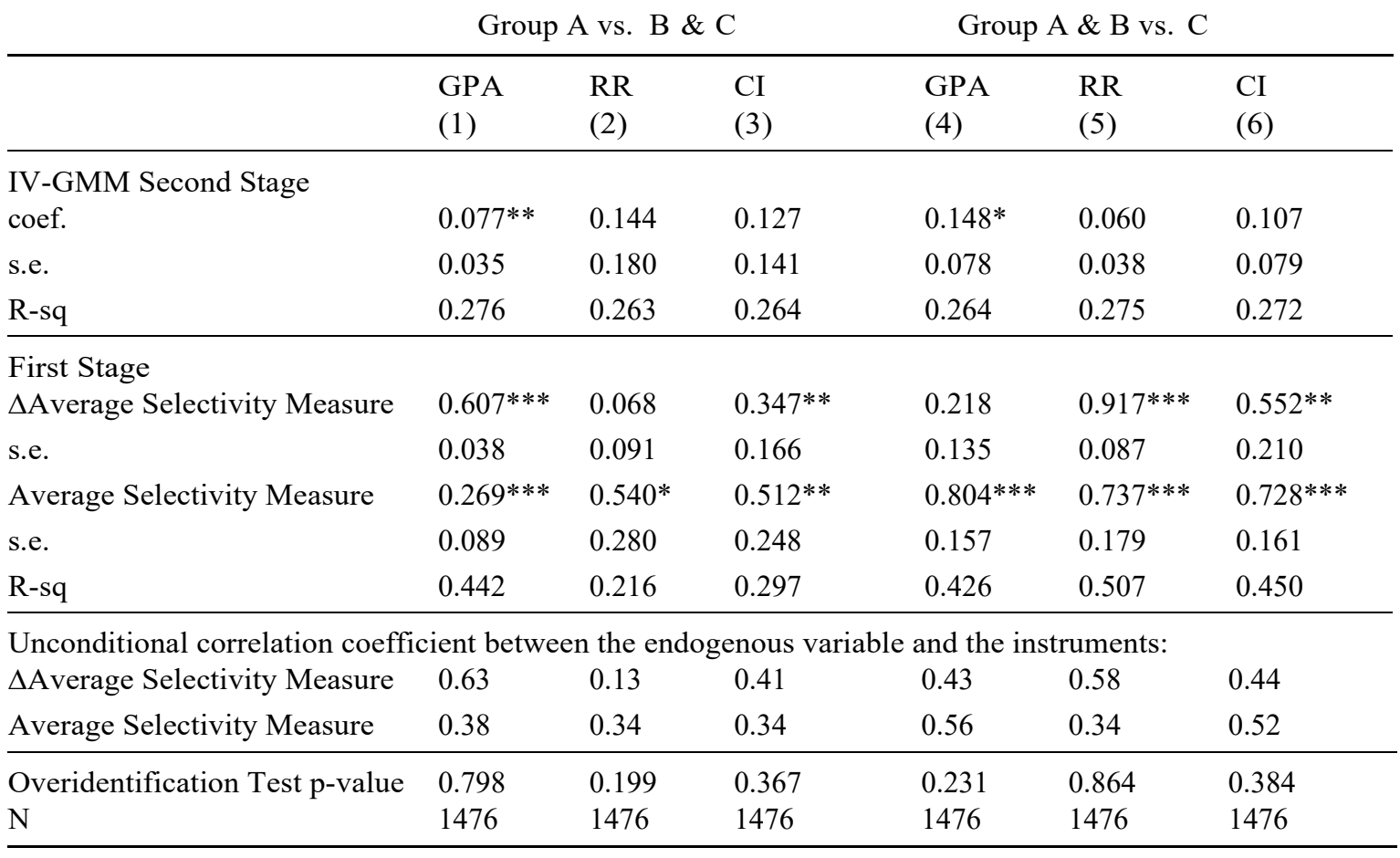

Treatment and comparison groups are indicated at the top of the columns. Standard error estimates are weighted and robust. The list of covariates not shown in the table is as listed and described in section 4.1. The treatment variables are defined as shown is Table 2 using the university type and the respective selectivity measure: Entering Cohort GPA (GPA), Reputation Ranking (RR), and the Composite Index (CI). coef. $=$ Coefficient estimate. s.e. $=$ Standard error estimate. R-sq= R-squared. $\mathrm{N}=$ Sample size. $* * * p<$ $0.01, * * \mathrm{p}<0.05, * \mathrm{p}<0.10$.

The IV estimates indicate a $8 \%$ premium on the hourly wage for those that graduated from a Group A university in comparison to other universities. The premium is $14.8 \%$ when the treatment is defined as graduating from a Group A or B university versus a Group $\mathrm{C}$ university. In both cases the treatment groups are defined using the Entering Cohort GPA as the selectivity measure. For the other cases when the treatment definition is based on the RR and the CI (columns (2), (3), (5) and (6)), the premium varies between $6-14.4 \%$ but is statistically insignificant. Finally, with respect to the estimate in column (4), even though the IV estimate is almost twice the ATT estimate of Table 3, they are statistically not different. 


\section{MILLA Canadian University Selectivity Premium}

\subsection{Robustness analysis}

Analyzing the distribution of the predicted probability of attending a better university as defined by each treatment variable, commonly referred to as the propensity score (PS), may allow us to look into another aspect of the student composition of the treatment and comparison groups. The PS is simply the predicted outcome from a logit equation of the treatment indicator variable on all covariates that I use in the multivariate matching to construct Table 3 estimates. The kernel density estimates are displayed in Figure A.1 and A.2. In the former the PS distribution for the treatment group is an almost symmetric bell shaped, whereas the distribution of the comparison group is right-skewed. In the latter the PS distribution for the treatment group is leftskewed and the one for the comparison group is right skewed. One may be concerned on whether the NNM estimates presented in Table 3 are driven by and reflect mostly the students with high PS. As a robustness check, I trimmed the tails of the PS distribution and kept the students whose PS score fell within the inter-quartile range (IQR). The empirical distributions are shown in Figures A.3 and A.4.

Using the IQR sample I reproduce the estimation results of Tables 3 and 4, and display the estimates in Tables A.6 and A.7. These estimates are very similar to the previous estimates that I retrieve using the full sample: LS estimates hover between 1$4 \%$ and are statistically insignificant; the NNM estimates of ATT effect are between 6$8 \%$ and statistically significant at conventional levels; ATC estimates are statistically equal to ATT estimates; the IV estimates provide a statistically premium of $8-13 \%$.

\subsection{Selection after enrollment}

The paper so far has discussed and addressed the issue of non-random selection of students in universities of different selectivity at the enrollment stage. What happens in the stages that follow after enrollment could also potentially lead to non-random selection.

Dropping out of university is likely to be systematically different across universities of different quality. Also, some of the students may take longer to graduate than others, and once they do, they may enter the labor market or pursue graduate studies. Those who enter the labor market may be working full time or part time. Any or all of these choices are also sources of sample selection which could potentially distort the estimation results if they are systematically correlated with university quality. In order to test the presence of this type of non-random selection, Table A.8 displays the regression results of several outcomes on the dummy indicators for the highest- and middle-third university groups, leaving lowest-third universities as the omitted category. These outcomes are: the probability of dropping out of university, time in months it took to complete the program and graduate, the probability of pursuing graduate school versus entering the labor 
market, the probability of being employed at the time of the survey, and the probability of being self-employed.

According to the grouping based on the Reputation ranking, group A university graduates are $6 \%$ less likely to drop out. Nevertheless, the outcome is not consistent across the other two types of groupings. The non-random selection due to dropping out behavior could be an issue with important consequences when working with data from countries where university retention and completion rates are low (e.g. Symonds, Schwartz, and Ferguson (2011) report a 56\% retention rate in the U.S.). Canada's universities have high retention rates of above $80 \%$. When both $\mathrm{RR}$ and the $\mathrm{CI}$ is used to form selectivity groups, graduates of group A universities are 5-6\% more likely to continue further their education with a graduate degree, and are about $4 \%$ more likely to find employment after graduation (the sample excludes the students enrolled in a graduate degree program). The former may lead to an estimate of the wage premium that is downward biased (since the better students of the top universities are out of the labor market), and the latter may lead to an overestimate (since group A graduates would be more present than group B \& C graduates). As long as these two effects translate into an equal proportion of bias in the wage premium, these may potentially cancel out. Lastly, from the third panel of Table A.8, graduates of group A or B universities take 0.05 months longer to graduate. This is a sufficiently small magnitude that is unlikely to affect the wage premium estimates.

\section{Conclusion}

Abundant evidence in the literature documents a positive and high wage premium to university selectivity. The majority of the studies use U.S. data or data from countries with a higher education system that are strongly differentiated. In this paper I survey the literature on wage premium of university selectivity and argue that not only the identification strategy and the method of estimation matter, but the characteristics of the different higher education systems also matter. I observe that the wage premium is lower in countries like Canada where the higher education is funded heavily through public funds and the universities are moderately differentiated in terms of selectivity.

In addition, I use the Youth in Transition Survey, a unique and previously unexploited data to estimate the wage premium to university selectivity in Canada. This is the first paper which attempts to tackle the issue of selection on unobservable characteristics in the context of Canada. Using a matching estimator, I estimate a $7 \%$ premium on the hourly wages of graduates to selective Canadian universities. The instrumental variable estimates, that are free of bias from unobserved variables, indicate a $14.8 \%$ premium. The two estimates are statistically not different. 


\section{MILLA Canadian University Selectivity Premium}

A question of immediate interest that has not been rigorously investigated in the literature is whether the positive premium of university selectivity changes in later career when the wage profile reaches equilibrium. Another question is related to separating between the potential channels that lead wages of observationally similar individuals to be $7-14.8 \%$ higher: Is it the quantity/quality of human capital transferred from the more selective universities or is it a beneficiary side effect of being in a network of better peers? Or is it simply signaling? Few recent efforts on early career wages provide support for the signaling scenario (Bordon and Braga, 2014; Lang and Siniver, 2011; Macleod et al., 2017) without unambiguously separating or ruling out the other potential mechanisms. These research questions are subject of future research upon availability of new data that permit such analysis.

\section{References}

Andrews, R. J., Li, J., and Lovenheim, M. F. (2016). Quantile treatment effects of college quality in earnings. The Journal of Human Resources, 51(1), 200-238.

Behrman, J. R., Rosenzweig, M. R., and Taubman, P. (1996). College choice and wages: Estimates using data on female twins. Review of Economics and Statistics, 78 (4), 672685.

Betts, J., Ferrall, C., and Finnie, R. (2013). The role of university characteristics in determining post-graduation outcomes: Panel evidence from three Canadian cohorts. Canadian Public Policy, 39(s1), 81-106.

Birch, E. R., Li, I., and Miller, P. W. (2009). The influences of institution attended and field of study on graduates' starting salaries. The Australian Economic Review, 42 (1), 42-63.

Black, D., Daniel, K., and Smith, J. (2005). College quality and the wages in the United States. German Economic Review, 6(3), 415-443.

Black, D. A., and Smith, J. A. (2004). How robust is the evidence on the effects of college quality? Evidence from matching. Journal of Econometrics, 121, 99-124.

Black, D. A., and Smith, J. A. (2006). Estimating the returns to college quality with multiple proxies for quality. Journal of Labor Economics, 24 (3), 701-728.

Bordon, P., and Braga, B. (2014). Employer learning, statistical discrimination and university prestige. Manuscript (April 2014).

Borgen, N. T. (2014). College quality and hourly wages: Evidence from the self- revelation model, sibling models and instrumental variables. Social Science Re- search, 48, 121134.

Brand, J. E., and Halaby, C. N. (2006). Regression and matching estimates of the effects of elite college attendance on educational and career achievement. Social Science Research, $35,749-770$.

Brewer, D., and Ehrenberg, R. (1996). Research in Labor Economics. In S. Polachek (Ed.), (Vol. 15, pp. 239-271). Greenwich, CT: JAI Press. 
Brewer, D. J., Eide, E. R., and Ehrenberg, R. G. (1999). Does it pay to attend an elite private college? Journal of Human Resources, 104-123.

Britton, J., Dearden, L., Shephard, N., and Vignoles, A. (2016, April). How English domiciled graduate earnings vary with gender, institution attended, subject and socio-economic background. Retrieved from http://www.ifs.org.uk/uploads/ publications /wps /wp201606.pdf doi: 10.1920/wp.ifs.2016.1606

Broecke, S. (2012). University selectivity and earnings: Evidence from UK data on applications and admissions to university. Economics of Education Review, 31, 96-107.

Brunello, G., and Cappellari, L. (2008). The labour market effects of Alma Mater: Evidence from Italy. Economics of Education Review, 27, 564-574.

Card, D. (1999). The causal effects of education on earnings. In O. Ashenfelter and D. Card (Eds.), Handbook of Labour Economics (Vol. 3, p. 1801-1863). Elsevier Science B.V.

CAUT. (2002). CAUT almanac of post-secondary education. Retrieved from https:// www.caut.ca/docs/almanac/almanac-2002.pdf?sfvrsn $=0$

Chen, W., Groveb, W. A., and Hussey, A. (2012). The payoff to school selectivity: An application of Dale and Krueger's method to MBA programs. Economics Letters, 116, 247-249.

Chevalier, A., and Conlon, G. (2003). Does it pay to attend a prestigious university? Center for Economics of Education, London School of Economics and Political Science, Houghton Street, London WC2A2AE.

Christofides, L., Hoy, M., Milla, J., and Stengos, T. (2015). Grades, aspriations and postsecondary education outcomes. Canadian Journal of Higher Education, 45(1), 48-82.

Cohodes, S. R., and Goodman, J. S. (2014, October). Merit aid, college quality, and college completion: Massachusetts' Adams Scholarship as an in-kind subsidy. American Economic Journal: Applied Economics, 6 (4), 251-85. doi: 10.1257/ app.6.4.251

Dale, S., and Krueger, A. B. (2002). Estimating the payoff to attending a more selective college: An application of selection on observables and unobservables. The Quarterly Journal of Economics, 79 (2), 1491-1527.

Dale, S. B., and Krueger, A. B. (2014). Estimating the effects of college characteristics over the career using administrative earnings data. The Journal of Human Resources, 49 (2), 324-358.

Dearden, L., Ferri, J., and Meghir, C. (2002). The effect of school quality on educational attainment and wages. The Review of Economics and Statistics, 84 (1), 1-20.

Goodman, J., Hurwitz, M., Smith, J., and Fox, J. (2015). The relationship between siblings' college choices: Evidence from one million SAT-taking families. Economics of Education Review, 48, 75-85. doi: http://dx.doi.org/10.1016/j.econedurev.2015.05.006

Grove, W. A., and Hussey, A. (2011). Returns to field of study versus school quality: MBA selection on observed and unobserved heterogeneity. Economic Inquiry, 49 (3), 730-749. 


\section{MILLA Canadian University Selectivity Premium}

Hansen, L. P. (1982). Large sample properties of generalized method of moments estimators. Econometrica, 50, 1029-1054.

Hanushek, E. A., Lavy, V., and Hitomi, K. (2008). Do students care about school quality? Determinants of dropout behavior in developing countries. Journal of Human Capital, 2 (1), 69-105.

Harmon, C., Oosterbeek, H., and Walker, I. (2003). The returns to education: Microeconomics. Journal of Economic Surveys, 17 (2), 115-155.

Hartoga, J., Sunb, Y., and Ding, X. (2010). University rank and bachelor's labour market positions in China. Economics of Education Review, 29, 971-979.

Heckman, J. J., and Robb, R. (1985). Alternative methods for evaluating the impact of interventions. Journal of Econometrics, 3, 239-267.

Heil, S., Reisel, L., and Attewell, P. (2014). College selectivity and degree completion. American Educational Research Journal, 51(5), 913-935.

Hoekstra, M. (2009). The effect of attending the flagship state university on earnings: A discontinuity-based approach. The Review of Economics and Statistics, 91 (4), 717-724.

Hoxby, C. (1997). How the changing market structure of U.S. higher education explains college tuition.

Hussain, I., McNally, S., and Telhaj, S. (2009). University quality and graduate wages in the UK (Centre for the Economics of Education (CEE) Discussion Paper No. 99).

James, E., Alsalam, N., Conaty, J. C., and To, D.-L. (1989). College quality and future earnings: Where should you send your child to college? AEA Papers and Proceedings, Economics of Education Industry, 79 (2), 247-252.

Jones, G. A. (2014). An introduction to higher education in Canada. In K. Joshi and S. Paivandi (Eds.), Higher education across nations. Delhi: B.R. Publishing.

Kaufmann, K. M., Messner, M., and Solis, A. (2014). The intergenerational effects of elite higher education: Evidence from Chile. Manuscript (March 2014).

Kaufmann, K. M., Messnerz, M., and Solis, A. (2013). Returns to elite higher education in the marriage market: Evidence from Chile. Unpublished Mimeo.

King, G., and Nielsen, R. (2016, December). Why propensity scores should not be used for matching. Working Paper. Retrieved from https://gking.harvard.edu/ files/gking/files/psnot.pdf

Lang, K., and Siniver, E. (2011). Why is an elite undergraduate education valuable? Evidence from Israel. Labour Economics, 18 (6), 767-777.

Lee, D. S., and Lemieux, T. (2010). Regression discontinuity designs in economics. Journal of Economic Literature, 48 (June) 281-355.

Lindahl, L., and Regnér, H. (2005). College choice and subsequent earnings: Results using Swedish sibling data. Scandinavian Journal of Economics, 107 (3), 437-457.

Long, M. C. (2008). College quality and early adult outcomes. Economics of Education Review, 27, 588-602. 
Long, M. C. (2010). Changes in the returns to education and college quality. Economics of Education Review, 29, 338-347.

Loury, L. D., and Garman, D. (1995). College selectivity and earnings. Journal of Labour Economics, 13(2), 289-308.

Loyalka, P., Song, Y., and Wei, J. (2012). The effects of attending selective college tiers in china. Social Science Research, 41 (2), 287 - 305. doi: http://dx.doi.org/10.1016/j.ssresearch.2011.11.015

Macleod, W. B., Riehl, E., Saavedra, J. E., and Urquiola, M. (2017). The big sort: College reputation and labor market outcomes. American Economic Journal: Applied Economics, 9 (3), 223-261.

Monks, J. (2000). The returns to individual and college characteristics, evidence from the National Longitudinal Survey of Youth. Economics of Education Review, 19, 279-289.

OECD. (2007). OECD thematic review of tertiary education. Retrieved from http:// www.oecd.org/edu/skills-beyond-school/39355618.pdf

OECD. (2013). Education at a glance. Retrieved from http://www.oecd.org/edu/Canada EAG2013\%20Country\%20Note.pdf

OECD. (2016). Education at a glance 2016: OECD indicators. doi: http://dx.doi.org/10.187/eag-2016-en

Saavedra, A. R., and Saavedra, J. E. (2011). Do colleges cultivate critical thinking, problem solving, writing and interpersonal skills? Economics of Education Review, 30, 1516-1526.

Saavedra, J. E. (2009). The learning and early labor market effects of college quality: A regression discontinuity analysis. Unpublished manuscript, Universidad de los Andes, School of Government.

Smith, J. A., and Todd, P. E. (2005). Does matching overcome LaLonde's critique of nonexperimental estimators? Journal of Econometrics, 125, 305-353.

Solis, A. (2013). Does higher education cause political participation? Evidence from a regression discontinuity design. Retrieved 23-08-2017, from http://uu.divaportal.org/smash/get/diva2:638723/FULLTEXT01.pdf (Retrieved: 23-082017)

Symonds, W. C., Schwartz, R., and Ferguson, R. F. (2011). Pathways to prosperity: Meeting the challenge of preparing young Americans for the 21st century. Retrieved 05- 02-2017, from http://nrs.harvard.edu/urn-3:HUL.InstRepos:4740480 (Retrieved: 05-02-2017)

Thistlewaite, D., and Campbell, D. (1960). Regression-discontinuity analysis: An alternative to the ex-post facto experiment. Journal of Educational Psychology, 51 (6), 309-317.

Triventi, M., and Trivellato, P. (2012). Does graduating from a private university make a difference? Evidence from Italy. European Journal of Education, 47 (2), 260-276.

Walker, I., and Zhu, Y. (2017). University selectivity and the graduate wage premium: Evidence from the UK (Discussion Paper No. 10536). 


\section{MILLA Canadian University Selectivity Premium}

\section{Appendix}

Table A1: Summary Statistics: Mean and St. Deviation (in brackets)

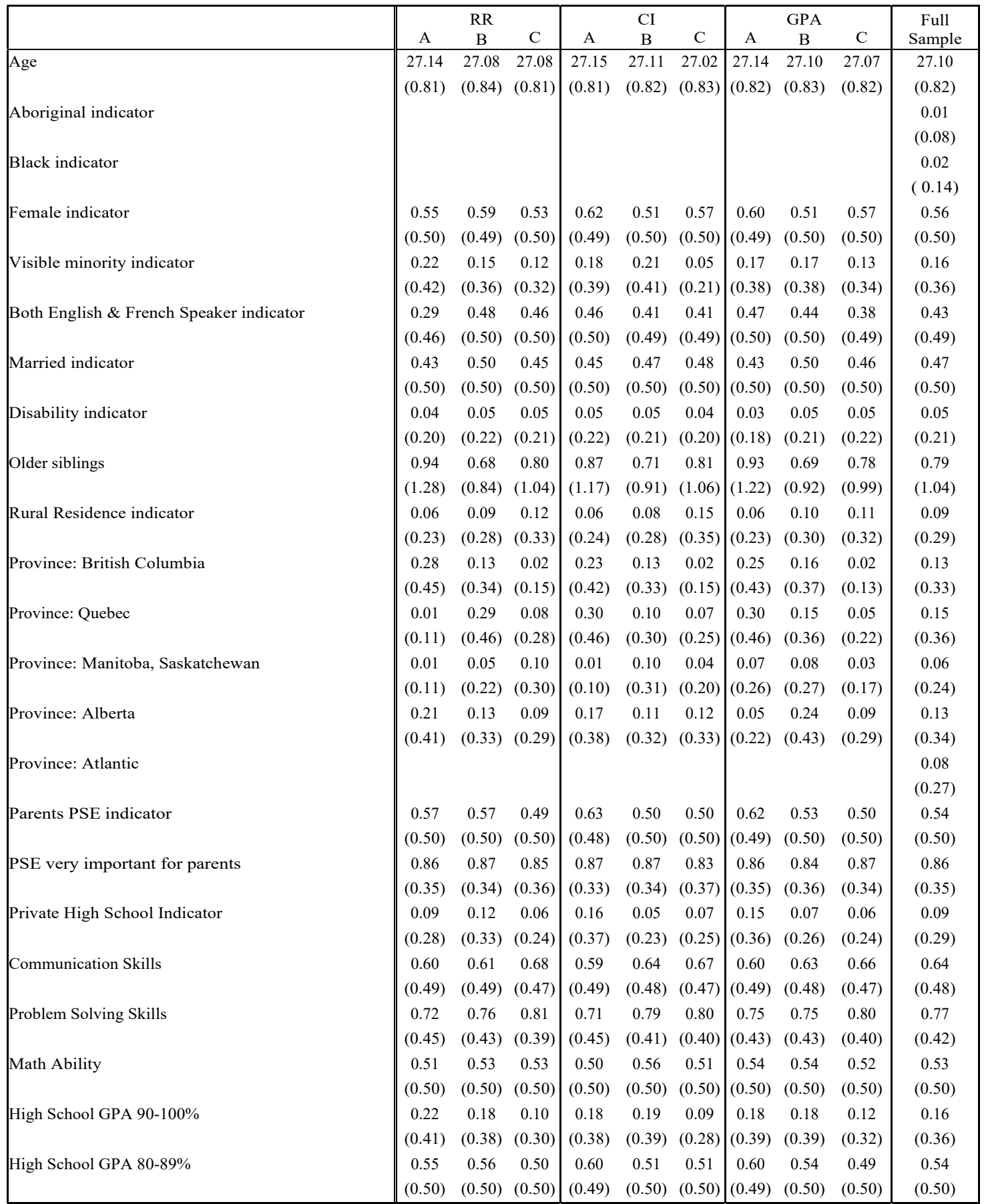


Review of Economic Analysis 10 (2018) 313-349

Table A1: Summary Statistics: Mean and (St. Deviation) (continued)

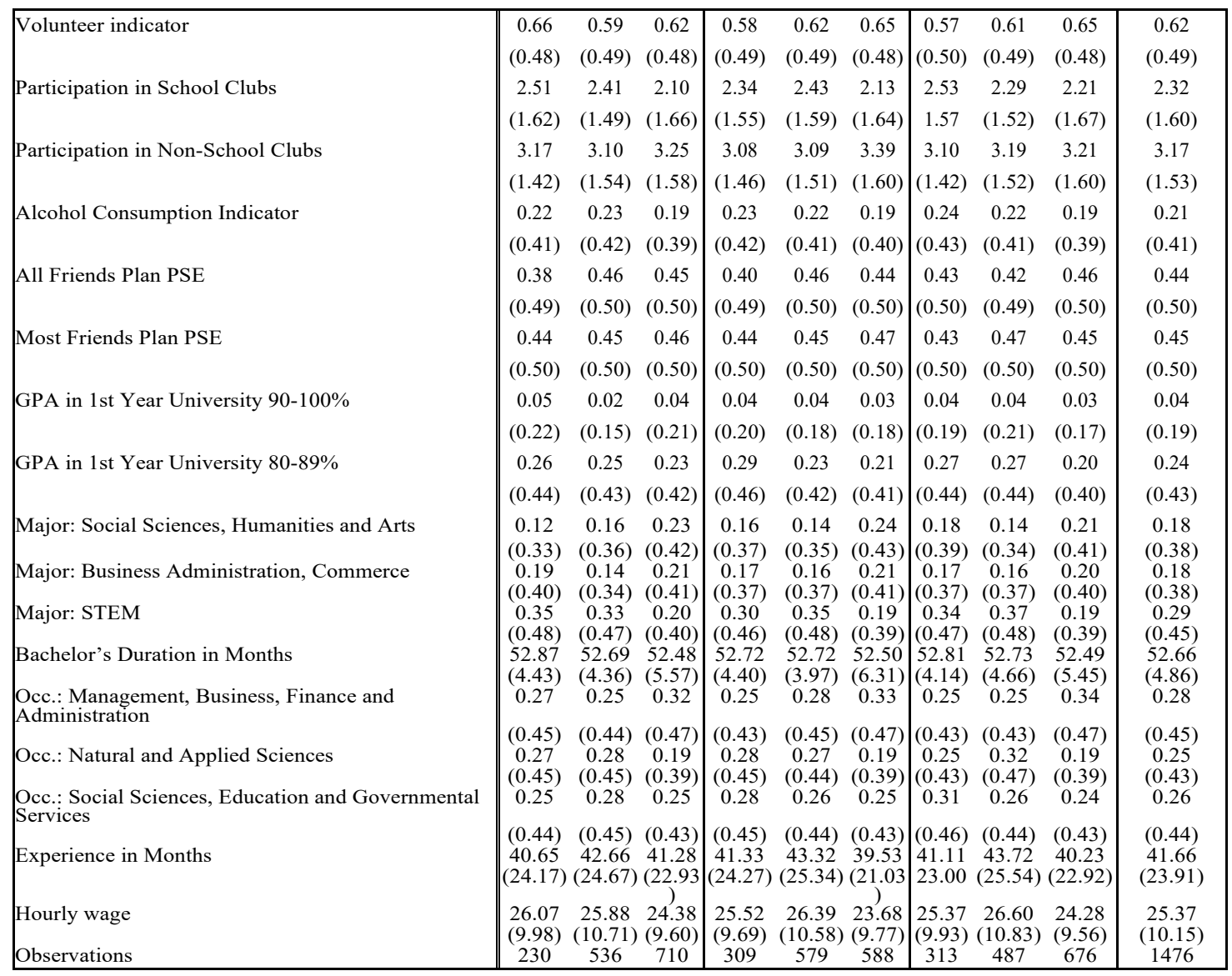

The descriptive statistics for the following variables were suppressed in the disclosure process for the desegregated samples due to small cell size: Atlantic provinces residence dummy, Black indicator, Aboriginal indicator. 


\section{MILLA Canadian University Selectivity Premium}

Table A.2: Correlation coefficients of regression variables

\begin{tabular}{|c|c|c|c|c|c|c|c|c|c|c|c|c|c|c|c|c|c|}
\hline & 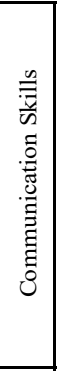 & 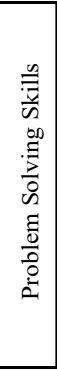 & 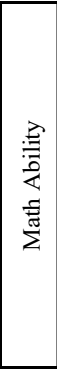 & 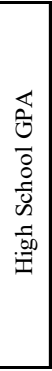 & 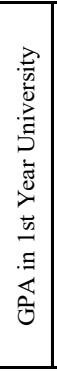 & 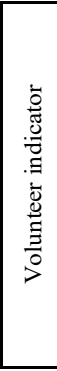 & 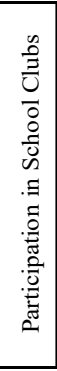 & 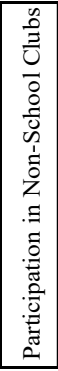 & $\stackrel{0}{8}$ & 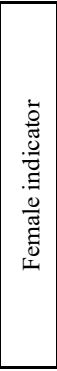 & 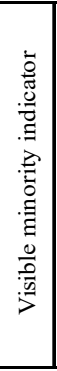 & 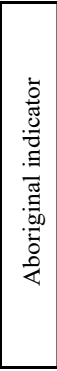 & 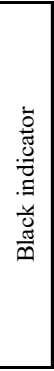 & 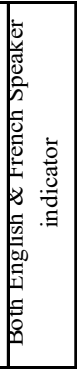 & 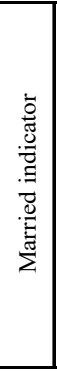 & 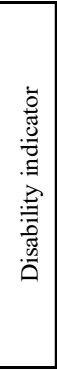 & 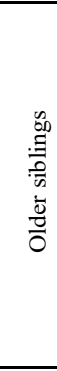 \\
\hline Communication Skills & 1 & & & & & & & & & & & & & & & & \\
\hline Problem Solving Skills & 0.5 & 1 & & & & & & & & & & & & & & & \\
\hline Math Ability & 0.1 & 0.1 & 1 & & & & & & & & & & & & & & \\
\hline High School GPA & 0 & 0.1 & 0.2 & 1 & & & & & & & & & & & & & \\
\hline GPA in 1st Year University & 0 & 0 & 0 & 0.4 & 1 & & & & & & & & & & & & \\
\hline Volunteer indicator & 0.1 & 0 & 0 & 0.1 & 0 & 1 & & & & & & & & & & & \\
\hline Participation in School Clubs & 0.2 & 0.1 & -0 & 0.2 & 0.1 & 0.2 & 1 & & & & & & & & & & \\
\hline Participation in Non-School Clubs & 0.1 & -0 & 0.1 & 0 & -0 & 0.2 & 0 & 1 & & & & & & & & & \\
\hline Age & 0 & -0 & -0 & -0 & -0 & -0 & -0 & 0 & 1 & & & & & & & & \\
\hline Female indicator & 0.1 & 0.1 & -0 & 0.1 & 0 & 0.1 & 0.1 & -0 & -0 & 1 & & & & & & & \\
\hline Visible minority indicator & -0 & 0 & 0.1 & 0 & 0 & 0 & -0 & -0 & -0 & -0 & 1 & & & & & & \\
\hline Aboriginal indicator & -0 & -0 & -0 & -0 & -0 & 0 & -0 & 0 & -0 & 0 & -0 & 1 & & & & & \\
\hline Black indicator & 0 & 0 & -0 & -0 & -0 & 0 & -0 & -0 & 0 & 0 & 0.4 & -0 & 1 & & & & \\
\hline Both English \& French Speaker indicator & 0.1 & 0.1 & 0 & 0.1 & 0.1 & 0.1 & 0.1 & -0 & -0 & 0.1 & -0 & -0 & 0.1 & 1 & & & \\
\hline Married indicator & 0.1 & -0 & -0 & 0.1 & 0.1 & 0 & 0.1 & 0.1 & 0.1 & 0.2 & -0 & 0 & -0 & 0.04 & 1 & & \\
\hline Disability indicator & 0 & 0 & -0 & -0 & 0 & 0 & 0 & -0 & -0 & 0 & -0 & 0 & -0 & 0.07 & 0 & 1 & \\
\hline Older siblings & -0 & -0 & 0 & -0 & 0.1 & 0 & 0 & -0 & -0 & 0.1 & -0 & -0 & 0 & -0 & 0 & 0.1 & 1 \\
\hline Private High School Indicator & -0 & 0 & 0 & -0 & 0 & -0 & 0 & -0 & -0 & 0 & 0 & -0 & 0.1 & 0.08 & -0 & 0 & 0.05 \\
\hline Rural Residence indicator & 0 & 0 & 0 & 0 & 0 & 0.1 & 0 & 0 & -0 & 0 & -0 & 0.1 & 0 & 0.02 & 0.1 & 0 & 0.13 \\
\hline Parents PSE indicator & 0.1 & 0 & 0 & 0.1 & 0.1 & 0 & 0.1 & 0.1 & -0 & -0 & -0 & -0 & 0 & 0.06 & 0.1 & -0 & -0 \\
\hline PSE very important for parents & 0 & 0.1 & -0 & -0 & 0 & 0.1 & 0.1 & -0 & 0 & 0.1 & 0.1 & -0 & 0.1 & 0.05 & -0 & -0 & -0 \\
\hline Alcohol Consumption Indicator & 0.1 & 0 & -0 & -0 & -0 & -0 & 0 & 0.1 & 0.1 & -0 & -0 & -0 & -0 & -0 & 0 & \begin{tabular}{|l|}
-0 \\
\end{tabular} & 0.07 \\
\hline \begin{tabular}{|l} 
All Friends Plan PSE \\
\end{tabular} & 0.1 & 0.1 & -0 & 0.1 & 0 & 0 & 0.1 & 0 & -0 & 0.1 & 0 & -0 & 0 & 0.13 & 0.1 & 0 & -0 \\
\hline Most Friends Plan PSE & -0 & -0 & 0 & -0 & 0 & 0 & -0 & 0 & 0.1 & -0 & 0 & 0.1 & 0 & -0.1 & -0 & -0 & 0 \\
\hline Major: Social Sciences, Humanities and Arts & -0 & -0 & 0.1 & -0 & -0 & -0 & -0 & 0 & 0.1 & -0 & 0.1 & 0 & 0 & 0.02 & -0 & 0 & 0.04 \\
\hline Major: Business Administration, Commerce & 0.2 & 0.1 & -0 & -0 & 0 & 0 & 0 & -0 & -0 & 0.1 & -0 & -0 & 0 & 0.08 & 0 & 0 & -0 \\
\hline Major: ST EM & -0 & -0 & 0.4 & 0.3 & 0.1 & 0 & -0 & -0 & -0 & -0 & 0 & 0 & -0 & \begin{tabular}{|c|}
-0.1 \\
\end{tabular} & -0 & -0 & 0.04 \\
\hline Bachelor's Duration in Months & 0 & 0 & 0 & -0 & 0 & 0.1 & 0.1 & -0 & 0 & -0 & 0 & 0 & 0.1 & 0 & -0 & -0 & 0.05 \\
\hline $\begin{array}{l}\text { Occ.: Management, Business, Finance and } \\
\text { Administration }\end{array}$ & 0 & 0 & 0.1 & -0 & -0 & -0 & -0 & -0 & -0 & 0 & 0.2 & -0 & 0.1 & -0 & -0 & -0 & 0.03 \\
\hline Occ.: Natural and Applied Sciences & -0 & -0 & 0.2 & 0.1 & 0.1 & -0 & 0 & -0 & -0 & -0 & 0 & 0 & -0 & -0 & 0 & 0 & 0.03 \\
\hline $\begin{array}{l}\text { Occ.: Social Sciences, Education and } \\
\text { Governmental Services }\end{array}$ & 0.1 & 0.1 & -0 & 0 & 0.1 & 0.1 & 0 & 0.1 & 0 & 0.2 & -0 & -0 & -0 & 0.04 & 0.1 & -0 & -0.1 \\
\hline Experience in Months & 0.1 & -0 & 0 & 0 & -0 & 0.1 & 0.1 & 0 & 0.3 & 0 & 0.1 & -0 & 0 & 0.01 & 0 & -0 & -0.1 \\
\hline Hourly Wage & 0.1 & -0 & 0.2 & 0.1 & 0.1 & 0.1 & 0.2 & -0 & 0.1 & -0 & 0 & -0 & -0 & -0 & 0.1 & -0 & 0.05 \\
\hline Reputation Ranking (RR) & 0.1 & 0.1 & 0 & -0 & -0 & -0 & -0 & 0 & -0 & 0 & -0 & 0.1 & 0 & 0.07 & 0 & 0 & -0 \\
\hline Composite Index $(\mathrm{CI})$ ranking & 0.1 & 0.1 & -0 & -0 & -0 & 0 & -0 & 0.1 & -0 & 0 & -0 & 0.1 & -0 & -0 & 0 & 0 & -0 \\
\hline GPA ranking & 0.1 & 0.1 & -0 & -0 & -0 & 0 & -0 & 0 & -0 & -0 & -0 & 0.1 & 0 & \begin{tabular}{|l|}
-0.1 \\
\end{tabular} & 0 & 0 & -0 \\
\hline
\end{tabular}


Review of Economic Analysis 10 (2018) 313-349

Table A.2: Correlation coefficients of regression variables (continued)

\begin{tabular}{|c|c|c|c|c|c|c|c|c|c|c|c|c|c|c|c|c|c|c|c|}
\hline & 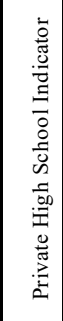 & 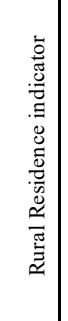 & 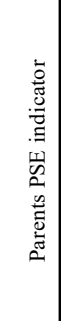 & 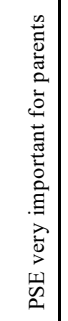 & 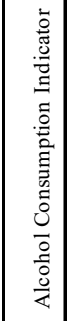 & 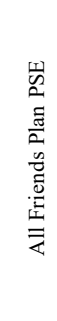 & 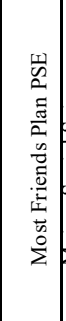 & 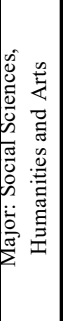 & 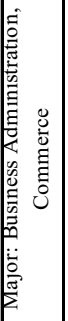 & 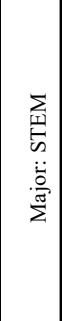 & 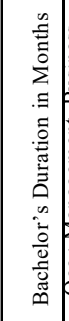 & 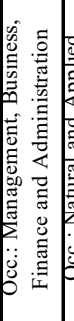 & 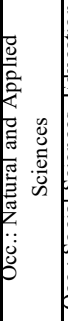 & 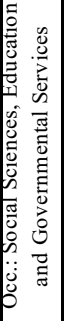 & 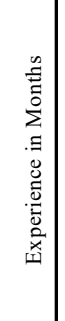 & 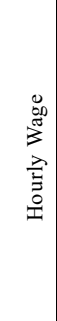 & 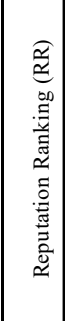 & 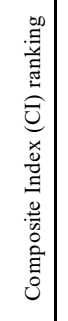 & 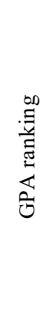 \\
\hline Private High School Indicator & 1 & & & & & & & & & & & & & & & & & & \\
\hline Rural Residence indicator & $\mid-0.1$ & 1 & & & & & & & & & & & & & & & & & \\
\hline Parents PSE indicator & 0.11 & -0 & 1 & & & & & & & & & & & & & & & & \\
\hline PSE very important for parents & 0 & -0.1 & \begin{tabular}{|c|c|c|c|c|c|}
0.09 \\
\end{tabular} & 1 & & & & & & & & & & & & & & & \\
\hline Alcohol Consumption Indicator & -0 & \begin{tabular}{|c|}
0.09 \\
\end{tabular} & \begin{tabular}{|c|}
0.06 \\
\end{tabular} & 0 & 1 & & & & & & & & & & & & & & \\
\hline All Friends Plan PSE & 0.11 & -0 & 0.07 & 0.02 & -0 & 1 & & & & & & & & & & & & & \\
\hline Most Friends Plan PSE & -0.1 & 0.03 & \begin{tabular}{l|l}
-0 & 0 \\
\end{tabular} & 0.02 & 0 & -0.8 & 1 & & & & & & & & & & & & \\
\hline Major: Social Sciences, Humanities and Arts & 0.08 & -0 & -0 & 0.06 & 0.01 & 0.01 & 0.01 & 1 & & & & & & & & & & & \\
\hline \begin{tabular}{|l|} 
Major: Business Administration, Commerce \\
\end{tabular} & -0 & 0 & \begin{tabular}{|c|}
0.02 \\
\end{tabular} & 0.04 & -0 & 0.02 & -0 & \begin{tabular}{|l|}
-0.2 \\
\end{tabular} & 1 & & & & & & & & & & \\
\hline Major: STEM & 0.01 & 0.01 & 0.03 & -0 & -0.1 & -0.1 & 0.07 & -0.3 & -0.3 & 1 & & & & & & & & & \\
\hline Bachelor's Duration in Months & 0.07 & \begin{tabular}{|c|}
0.01 \\
\end{tabular} & -0 & 0.04 & $\overline{0}$ & -0.1 & 0.07 & -0 & 0 & 0.05 & 1 & & & & & & & & \\
\hline $\begin{array}{l}\text { Occ.: Management, Business, Finance and } \\
\text { Administration }\end{array}$ & $\mid-0.1$ & -0.1 & -0.1 & 0.06 & -0 & -0 & -0 & 0.41 & -0.1 & $\mid-0.2$ & 0.04 & 1 & & & & & & & \\
\hline Occ.: Natural and Applied Sciences & 0.06 & 0.03 & -0.1 & -0 & -0.1 & -0.1 & 0.04 & -0.2 & -0.2 & 0.44 & 0.05 & \begin{tabular}{l|l}
-0.4 \\
\end{tabular} & 1 & & & & & & \\
\hline $\begin{array}{l}\text { Occ.: Social Sciences, Education and } \\
\text { Governmental Services }\end{array}$ & 0.07 & 0.06 & 0.08 & -0 & 0 & 0.06 & -0 & -0.2 & 0.17 & $|-0.1|$ & -0.1 & -0.4 & -0.3 & 1 & & & & & \\
\hline Experience in Months & -0.1 & -0.1 & \begin{tabular}{l|l}
-0 & 0 \\
\end{tabular} & 0.03 & 0.02 & -0.1 & 0.04 & 0.07 & -0 & -0.1 & 0.01 & 0.05 & -0 & -0.1 & 1 & & & & \\
\hline \begin{tabular}{|l} 
Hourly Wage \\
\end{tabular} & $\overline{0}$ & \begin{tabular}{c|}
-0 \\
\end{tabular} & \begin{tabular}{|l|}
0.02 \\
\end{tabular} & \begin{tabular}{|c|}
0.03 \\
\end{tabular} & 0.03 & 0.06 & -0 & 0.09 & -0.2 & 0.14 & 0.01 & \begin{tabular}{c|}
-0.1 \\
\end{tabular} & 0.22 & -0.1 & 0.09 & 1 & & & \\
\hline Reputation Ranking (RR) & -0.1 & 0.06 & \begin{tabular}{|c|}
-0.1 \\
\end{tabular} & -0.1 & 0.01 & 0.02 & 0.02 & 0.15 & 0.03 & \begin{tabular}{|c|}
-0.2 \\
\end{tabular} & -0 & \begin{tabular}{|c|}
0.08 \\
\end{tabular} & -0.1 & 0 & \begin{tabular}{l|l} 
\\
\end{tabular} & -0.1 & 1 & & \\
\hline \begin{tabular}{|l|} 
Composite Index $(\mathrm{CI})$ ranking \\
\end{tabular} & \begin{tabular}{|l|}
-0.1 \\
\end{tabular} & 0.08 & \begin{tabular}{|c|}
-0.1 \\
\end{tabular} & \begin{tabular}{|c|}
-0.1 \\
\end{tabular} & -0 & 0.04 & 0.02 & 0.13 & 0.08 & \begin{tabular}{|l|}
-0.2 \\
\end{tabular} & -0 & 0.1 & -0.1 & -0 & 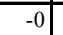 & -0.1 & \begin{tabular}{|l|}
0.79 \\
\end{tabular} & 1 & \\
\hline GPA ranking & -0.1 & 0.05 & \begin{tabular}{|l|}
-0.1 \\
\end{tabular} & -0.1 & -0 & 0.04 & 0 & 0.09 & 0.05 & \begin{tabular}{|l|}
-0.1 \\
\end{tabular} & -0 & 0.11 & -0.1 & -0.1 & \begin{tabular}{l|l}
-0 & -1 \\
\end{tabular} & -0.1 & \begin{tabular}{|c|}
0.77 \\
\end{tabular} & 0.84 & \\
\hline
\end{tabular}


MILLA Canadian University Selectivity Premium

Figure A.1: Propensity score distribution of Group A vs. B \& C

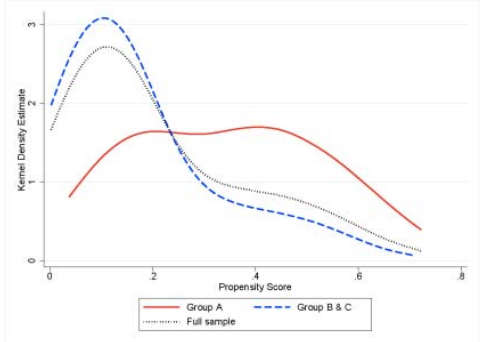

(a) GPA

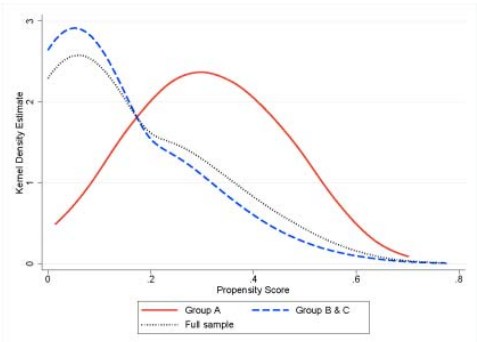

(b) RR

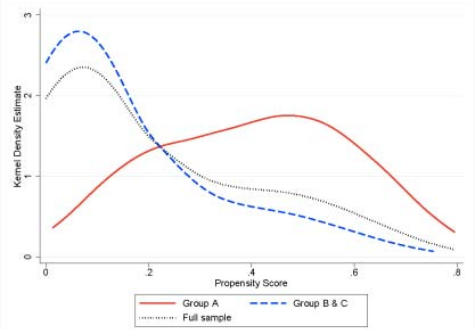

(c) $\mathrm{CI}$

Figure A.2: Propensity score distribution of Group A \& B vs. C

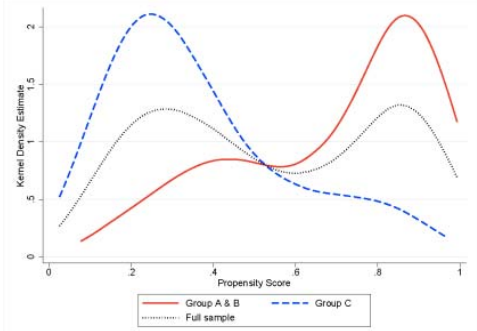

(a) GPA

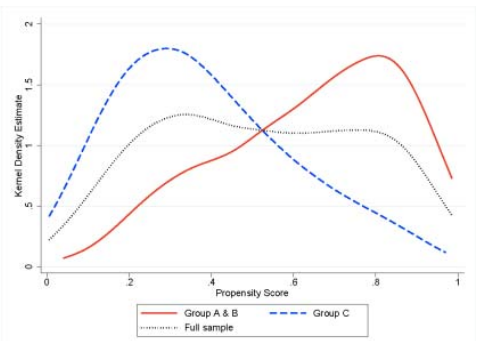

(b) RR

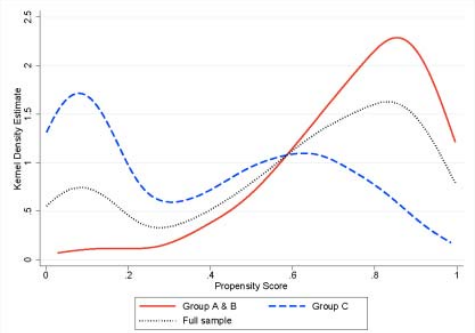

(c) $\mathrm{CI}$ 
Review of Economic Analysis 10 (2018) 313-349

Figure A.3: Propensity score distribution of Group A vs. B \& C of the IQR

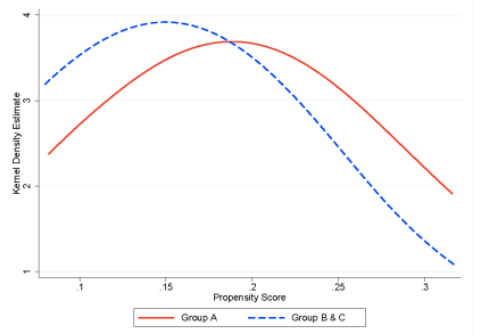

(a) GPA

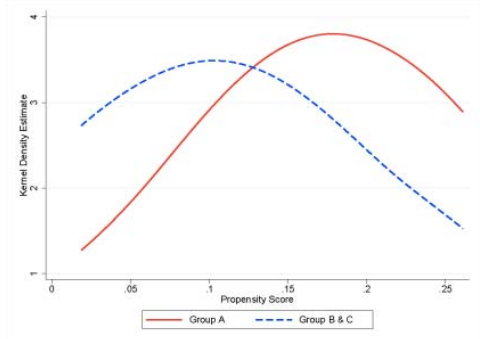

(b) RR

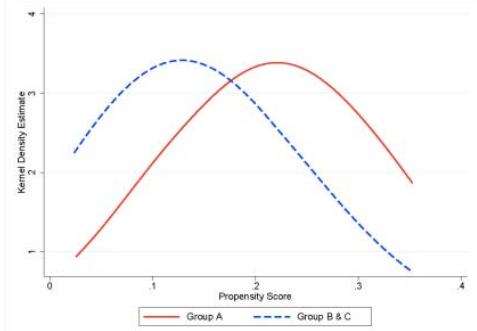

(c) $\mathrm{CI}$

Figure A.4: Propensity score distribution of Group A \& B vs. C of the IQR

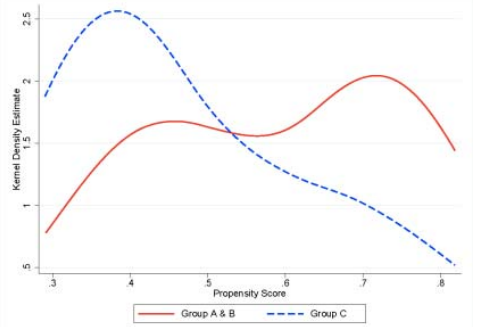

(a) GPA

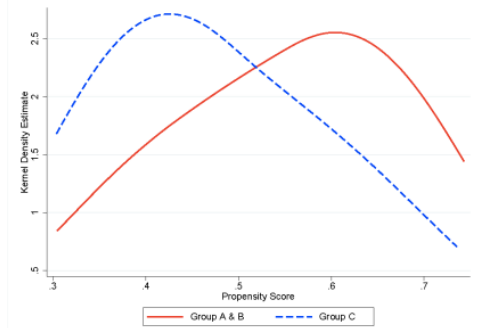

(b) RR

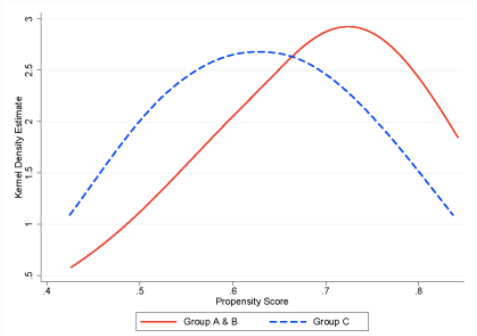

(c) $\mathrm{CI}$ 
MILLA Canadian University Selectivity Premium

Table A.3: Summary statistics and the weighting scheme of university characteristics

\begin{tabular}{|l|c|c|c|c|c|}
\hline Variable & Composite Index Weight & Mean & Standard Deviation & Minimum & Maximum \\
\hline Entering Cohort GPA & 0.431 & 81.617 & 3.467 & 75 & 89 \\
Faculty-Student Ratio & 0.083 & 0.198 & 0.043 & 0.100 & 0.280 \\
Faculty with PhDs & 0.369 & 88.078 & 10.866 & 38.2 & 98.400 \\
Student Awards & 0.494 & 3.563 & 2.307 & 0.200 & 9.500 \\
Faculty Awards & 0.462 & 3.534 & 3.021 & 0 & 10.700 \\
SSHR Grants Number & 0.462 & 16.615 & 11.051 & 1.500 & 47.730 \\
\hline
\end{tabular}

Table A.4: Correlation coefficients among university characteristics used to build the Composite Index (CI) ranking

\begin{tabular}{|c|c|c|c|c|c|c|}
\hline & $\begin{array}{c}\text { Entering } \\
\text { Cohort } \\
\text { GPA }\end{array}$ & $\begin{array}{c}\text { Faculty- } \\
\text { Student } \\
\text { Ratio }\end{array}$ & $\begin{array}{c}\text { Faculty } \\
\text { with PhDs }\end{array}$ & $\begin{array}{l}\text { Student } \\
\text { Awards }\end{array}$ & $\begin{array}{l}\text { Faculty } \\
\text { Awards }\end{array}$ & $\begin{array}{c}\text { SSHR } \\
\text { Number }\end{array}$ \\
\hline Entering Cohort GPA & 1 & & & & & \\
\hline Faculty-Student Ratio & 0.29 & 1 & & & & \\
\hline Faculty with PhDs & 0.47 & -0.01 & 1 & & & \\
\hline Student Awards & 0.74 & 0.3 & 0.6 & 1 & & \\
\hline Faculty Awards & 0.64 & 0.08 & 0.51 & 0.81 & 1 & \\
\hline SSHR Number & 0.64 & 0.09 & 0.55 & 0.77 & 0.75 & 1 \\
\hline
\end{tabular}


Review of Economic Analysis 10 (2018) 313-349

Table A.5: List of universities in each group that is defined in accordance with Table 2

\begin{tabular}{|c|c|c|c|}
\hline Group & RR \& University type & CI \& University type & GPA \& University type \\
\hline A & $\begin{array}{l}\text { McGill } \\
\text { Toronto } \\
\text { UBC } \\
\text { Alberta } \\
\text { Queen's } \\
\text { McMaster } \\
\text { Western }\end{array}$ & $\begin{array}{l}\text { McGill } \\
\text { Toronto } \\
\text { UBC } \\
\text { Alberta } \\
\text { Queen's } \\
\text { McMaster } \\
\text { Montreal } \\
\text { Laval }\end{array}$ & $\begin{array}{c}\text { McGill } \\
\text { Toronto } \\
\text { UBC } \\
\text { Saskatchewan } \\
\text { Queen's } \\
\text { Sherbrooke } \\
\text { Montreal } \\
\text { Western }\end{array}$ \\
\hline B & $\begin{array}{c}\text { Montreal } \\
\text { Dalhousie } \\
\text { Sherbrooke } \\
\text { Guelph } \\
\text { Waterloo } \\
\text { Simon Fraser } \\
\text { Laval } \\
\text { Victoria } \\
\text { York } \\
\text { Saskatchewan } \\
\text { Memorial } \\
\text { Calgary }\end{array}$ & $\begin{array}{c}\text { Western } \\
\text { Ottawa } \\
\text { Dalhousie } \\
\text { Guelph } \\
\text { Waterloo } \\
\text { Simon Fraser } \\
\text { Saskatchewan } \\
\text { Victoria } \\
\text { York } \\
\text { Manitoba } \\
\text { Carleton } \\
\text { Calgary } \\
\text { Sherbrooke } \\
\end{array}$ & $\begin{array}{c}\text { Dalhousie } \\
\text { Ottawa } \\
\text { Calgary } \\
\text { Guelph } \\
\text { Waterloo } \\
\text { Simon Fraser } \\
\text { Laval } \\
\text { Victoria } \\
\text { Alberta } \\
\text { Manitoba }\end{array}$ \\
\hline C & $\begin{array}{c}\text { Acadia } \\
\text { Wilfrid Laurier } \\
\text { Mount Allison } \\
\text { St. Francis Xavier } \\
\text { New Brunswick } \\
\text { Manitoba } \\
\text { Carleton } \\
\text { Lethbridge } \\
\text { Ottawa } \\
\text { Concordia } \\
\text { Saint Mary's } \\
\text { Ryerson } \\
\text { Windsor } \\
\text { Bishop's } \\
\text { Winnipeg } \\
\text { Mount Saint Vincent } \\
\text { Moncton } \\
\text { Cape Breton } \\
\text { Nipissing } \\
\text { Laurentian } \\
\text { St. Thomas } \\
\text { Brandon } \\
\text { Brock } \\
\text { UNBC } \\
\text { UPEI } \\
\text { Trent } \\
\text { Lakehead }\end{array}$ & $\begin{array}{c}\text { Mount Allison } \\
\text { St. Francis Xavier } \\
\text { New Brunswick } \\
\text { Concordia } \\
\text { Memorial } \\
\text { Wilfrid Laurier } \\
\text { UNBC } \\
\text { Lakehead } \\
\text { Acadia } \\
\text { Trent } \\
\text { Saint Mary's } \\
\text { Ryerson } \\
\text { Windsor } \\
\text { Bishop's } \\
\text { Winnipeg } \\
\text { Mount Saint Vincent } \\
\text { Moncton } \\
\text { Cape Breton } \\
\text { Nipissing } \\
\text { Laurentian } \\
\text { St. Thomas } \\
\text { Brandon } \\
\text { Brock } \\
\text { Lethbridge } \\
\text { UPEI }\end{array}$ & $\begin{array}{c}\text { Acadia } \\
\text { Wilfrid Laurier } \\
\text { Mount Allison } \\
\text { St. Francis Xavier } \\
\text { New Brunswick } \\
\text { Carleton } \\
\text { Lethbridge } \\
\text { York } \\
\text { Concordia } \\
\text { Saint Mary's } \\
\text { Ryerson } \\
\text { Windsor } \\
\text { Bishop's } \\
\text { Winnipeg } \\
\text { Mount Saint Vincent } \\
\text { Moncton } \\
\text { Cape Breton } \\
\text { Nipissing } \\
\text { Laurentian } \\
\text { St. Thomas } \\
\text { Brandon } \\
\text { Brock } \\
\text { UNBC } \\
\text { UPEI } \\
\text { Trent } \\
\text { Lakehead } \\
\text { Carleton } \\
\text { McMaster }\end{array}$ \\
\hline
\end{tabular}

For details on the group classifications (A, B, C) see Table 2. Acronyms for the selectivity measures are as follows: GPA: Entering Cohort GPA, RR: Reputation Ranking, CI: Composite Index 
MILLA Canadian University Selectivity Premium

Table A.6: Least squares and matching estimates of wage premium, IQR sample

\begin{tabular}{|c|c|c|c|c|c|c|}
\hline & \multicolumn{3}{|c|}{ Group A vs. B \& C } & \multicolumn{3}{|c|}{ Group A \& B vs. C } \\
\hline & $\begin{array}{l}\text { GPA } \\
\text { (1) }\end{array}$ & $\begin{array}{l}\mathrm{RR} \\
\text { (2) }\end{array}$ & $\begin{array}{l}\text { CI } \\
(3)\end{array}$ & $\begin{array}{l}\text { GPA } \\
(4)\end{array}$ & $\begin{array}{l}\mathrm{RR} \\
(5)\end{array}$ & $\begin{array}{l}\text { CI } \\
(6)\end{array}$ \\
\hline \multicolumn{7}{|c|}{ Least Squares Estimator } \\
\hline coef. & 0.041 & 0.006 & 0.038 & 0.034 & 0.038 & 0.038 \\
\hline s.e. & 0.037 & 0.046 & 0.030 & 0.029 & 0.030 & 0.028 \\
\hline R-sq & 0.312 & 0.282 & 0.274 & 0.303 & 0.289 & 0.287 \\
\hline \multicolumn{7}{|c|}{ Matching Estimates, ATT } \\
\hline coef. & 0.070 & 0.023 & 0.033 & $0.059^{*}$ & $0.078 * *$ & $0.058 *$ \\
\hline s.e. & 0.045 & 0.053 & 0.046 & 0.033 & 0.033 & 0.034 \\
\hline \multicolumn{7}{|c|}{ Matching Estimates, ATC } \\
\hline coef. & $0.102 * * *$ & 0.063 & 0.061 & $0.106^{* * *}$ & $0.078 * *$ & $0.069 *$ \\
\hline s.e. & 0.040 & 0.051 & 0.051 & 0.033 & 0.032 & 0.035 \\
\hline $\mathrm{N}$ & 738 & 738 & 738 & 738 & 738 & 738 \\
\hline
\end{tabular}

Treatment and comparison groups are indicated at the top of the columns. Standard error estimates are weighted and robust. The list of covariates not shown in the table is as listed and described in section 4.1. The treatment variables are defined as shown is Table 2 using the university type and the respective selectivity measure: Entering Cohort GPA (GPA), Reputation Ranking (RR), and the Composite Index (CI). IQR sample $=$ The sample used for these results is composed of individuals with a propensity score (PS) estimate that falls within the Inter-quartile range of the PS distribution. ATT $=$ Average Treatment on the Treated. ATC $=$ Average Treatment on the Control. coef. $=$ Coefficient estimate. s.e. $=$ Standard error estimate. $\mathrm{R}$-sq= R-squared. $\mathrm{N}=$ Sample size. ${ }^{* * *} \mathrm{p}<0.01,{ }^{* *} \mathrm{p}<0.05,{ }^{*} \mathrm{p}<0.10$ 
Review of Economic Analysis 10 (2018) 313-349

Table A.7: Instrumental variable estimates of wage premium, IQR sample

\begin{tabular}{lllllll}
\multicolumn{3}{c}{ Group A vs. } & B \& C & & \multicolumn{3}{c}{ Group A \& B vs. C } \\
\cline { 1 - 2 } \cline { 5 - 6 } GPA & RR & CI & & GPA & RR & CI \\
$(1)$ & $(2)$ & $(3)$ & & (4) & $(5)$ & $(6)$
\end{tabular}

\begin{tabular}{lllllll}
\hline IV-GMM Second Stage & & & & & & \\
coef. & $0.089^{*}$ & -0.386 & 0.021 & $0.131^{*}$ & $0.080^{*}$ & 0.107 \\
s.e. & 0.048 & 0.344 & 0.140 & 0.076 & 0.045 & 0.089 \\
R-sq & 0.300 & 0.260 & 0.287 & 0.277 & 0.291 & 0.273 \\
$\mathrm{~N}$ & 738 & 738 & 738 & 738 & 738 & 738 \\
\hline First Stage & & & & & & \\
$\Delta$ Average Selectivity Measure & $0.608^{* * *}$ & 0.080 & $0.388^{* *}$ & $0.236^{*}$ & $0.885^{* * *}$ & $0.664^{* * *}$ \\
s.e. & 0.042 & 0.097 & 0.161 & 0.136 & 0.109 & 0.222 \\
Average Selectivity Measure & $0.322^{* * *}$ & $0.254^{*}$ & $0.493^{* *}$ & $0.936^{* * *}$ & $0.885^{* * *}$ & $0.837^{* * *}$ \\
s.e. & 0.108 & 0.135 & 0.236 & 0.204 & 0.218 & 0.192 \\
R-sq & 0.390 & 0.135 & 0.209 & 0.311 & 0.415 & 0.393 \\
\hline Overidentification Test & 0.720 & 0.357 & 0.012 & 0.363 & 0.743 & 0.242 \\
$\mathrm{~N}$ & 738 & 738 & 738 & 738 & 738 & 738 \\
\hline
\end{tabular}

Treatment and comparison groups are indicated at the top of the columns. Standard error estimates are weighted and robust. The list of covariates not shown in the table is as listed and described in section 4.1. The treatment variables are defined as shown is Table 2 using the university type and the respective selectivity measure: Entering Cohort GPA (GPA), Reputation Ranking (RR), and the Composite Index (CI). IQR sample= The sample used for these results is composed of individuals with a propensity score (PS) estimate that falls within the Inter-quartile range of the PS distribution. coef. $=$ Coefficient estimate. s.e. $=$ Standard error estimate. R-sq= R-squared. $\mathrm{N}=$ Sample size. ${ }^{* * *} \mathrm{p}<0.01,{ }^{* *} \mathrm{p}<0.05,{ }^{*} \mathrm{p}<0$. 
MILLA Canadian University Selectivity Premium

Table A.8: Testing for sample selection after enrollment Group A vs. B \& Group A \& B vs. C

\begin{tabular}{llllll}
\hline GPA & RR & CI & GPA & RR & CI
\end{tabular}
(1)
(2)
(3)
(4)
(5)
(6)

\begin{tabular}{|c|c|c|c|c|c|c|}
\hline \multicolumn{7}{|c|}{$\operatorname{Pr}($ Drop out of university program) } \\
\hline coef. & -0.011 & $-0.060 * * *$ & -0.019 & -0.013 & 0.003 & -0.013 \\
\hline s.e. & 0.016 & 0.020 & 0.016 & 0.014 & 0.013 & 0.014 \\
\hline (Pseudo) R-sq & 0.229 & 0.235 & 0.229 & 0.229 & 0.228 & 0.229 \\
\hline $\mathrm{N}$ & 2230 & 2230 & 2230 & 2230 & 2230 & 2230 \\
\hline \multicolumn{7}{|c|}{$\operatorname{Pr}($ Graduate degree $)$} \\
\hline coef. & 0.005 & $0.051 * *$ & $0.060 * * *$ & 0.015 & -0.007 & 0.015 \\
\hline s.e. & 0.021 & 0.023 & 0.021 & 0.020 & 0.018 & 0.021 \\
\hline (Pseudo) R-sq & 0.045 & 0.047 & 0.049 & 0.045 & 0.045 & 0.045 \\
\hline $\mathrm{N}$ & 2089 & 2089 & 2089 & 2089 & 2089 & 2089 \\
\hline \multicolumn{7}{|c|}{ Bachelor's duration in months } \\
\hline coef. & -0.004 & -0.032 & -0.030 & 0.003 & $0.049 * * *$ & 0.012 \\
\hline s.e. & 0.017 & 0.021 & 0.019 & 0.017 & 0.016 & 0.018 \\
\hline R-sq & 0.036 & 0.036 & 0.036 & 0.036 & 0.038 & 0.036 \\
\hline $\mathrm{N}$ & 2089 & 2089 & 2089 & 2089 & 2089 & 2089 \\
\hline \multicolumn{7}{|c|}{$\operatorname{Pr}($ Employment $)$} \\
\hline coef. & 0.019 & $0.041 * * *$ & $0.043 * * *$ & 0.016 & 0.013 & 0.017 \\
\hline s.e. & 0.014 & 0.015 & 0.015 & 0.015 & 0.014 & 0.016 \\
\hline (Pseudo) R-sq & 0.103 & 0.110 & 0.112 & 0.103 & 0.103 & 0.103 \\
\hline $\mathrm{N}$ & 1679 & 1679 & 1679 & 1679 & 1679 & 1679 \\
\hline \multicolumn{7}{|c|}{$\operatorname{Pr}($ Self-employed) } \\
\hline coef. & 0.007 & 0.002 & 0.004 & 0.002 & 0.011 & 0.005 \\
\hline s.e. & 0.011 & 0.013 & 0.012 & 0.012 & 0.012 & 0.012 \\
\hline (Pseudo) R-sq & 0.176 & 0.175 & 0.175 & 0.175 & 0.177 & 0.175 \\
\hline $\mathrm{N}$ & 1505 & 1505 & 1505 & 1505 & 1505 & 1505 \\
\hline
\end{tabular}

Treatment and comparison groups are indicated at the top of the columns. Standard error estimates are weighted and robust. The list of covariates not shown in the table is as listed and described in section 4.1. The treatment variables are defined as shown is Table 2 using the university type and the respective selectivity measure: Entering Cohort GPA (GPA), Reputation Ranking (RR), and the Composite Index (CI). coef.=Coefficient estimate. s.e.= Standard error estimate. R-sq= R-squared. $\mathrm{N}=$ Sample size. $* * * \mathrm{p}<0.01, * * \mathrm{p}<0.05,{ }^{*} \mathrm{p}<0.10$. 